\title{
AN ECO-INNOVATIVE FRAMEWORK DEVELOPMENT FOR SUSTAINABLE CONSUMPTION AND PRODUCTION IN THE CONSTRUCTION INDUSTRY
}

\author{
Li MA $^{1,2}$, Liang WANG ${ }^{1}$, Miroslaw J. SKIBNIEWSKI ${ }^{3,4,5^{*}}$, Waldemar GAJDA ${ }^{6}$ \\ ${ }^{1}$ Department of Construction Management, Dalian University of Technology, Dalian, China \\ ${ }^{2}$ School of Business, Dalian University of Technology, Panjin, China \\ ${ }^{3}$ Department of Civil and Environmental Engineering, University of Maryland, College Park, USA \\ ${ }^{4}$ Research Board Member \& Professor, Institute for Theoretical and Applied Informatics, \\ Polish Academy of Sciences, Gliwice, Poland \\ ${ }^{5}$ T.-S. Yang Honorary Distinguished Professor, Chaoyang University of Technology, Taichung, Taiwan \\ ${ }^{6}$ Warsaw Management School - Graduate and Postgraduate School, Siedmiogrodzka 3A, \\ 01-204 Warszawa, Poland
}

Received 21 October 2018; accepted 26 January 2019

\begin{abstract}
Sustainable consumption and production have been increasingly required in the construction industry. However, previous studies have not yet comprehensively developed evaluation tools and methods to implement sustainable consumption and production. To achieve this objective, we utilized the eco-innovation, which provides effective analysis of sustainable consumption and production for the construction firms by eliminating subjectivity and ambiguity of evaluations. We adopted the fuzzy set theory to overcome the uncertainty occurring from the judgments of experts and utilized decision-making trial and evaluation laboratory approach to analyse the causal relationships between our methods and evaluation criteria. The results showed that environment and sustainable consumption are the key factors, while life cycle assessment, eco-labels, and environmental certification as well as improving eco-efficiency are critical to realizing sustainable consumption and production. The study enhances the understanding of the major players to achieve sustainable consumption and production, and link sustainable consumption and production with the eco-innovative practices. Our approach also improves the assessment accuracy, and the results provide viable suggestions for practical applications.
\end{abstract}

Keywords: sustainable consumption and production, fuzzy set theory, eco-innovation, decisionmaking trial and evaluation laboratory.

JEL Classification: D81, E21, E23, Q56.

*Corresponding author. E-mail: wltruth@mail.dlut.edu.cn 


\section{Introduction}

Construction industry generates a heavy burden on the environment and society with the increasing pace of economic development (Gan, Zuo, Ye, Skitmore, \& Xiong, 2015). Current consumption patterns and production systems rely on traditional practices and older technologies that are highly inefficient, generating a great amount of waste and high energy consumption; thus, they cause various environmental issues, such as environmental pollution, greenhouse gas emission, and excessive consumption of resources (Berg, 2011; Akbiyikli, Eaton, \& Dikmen, 2012; Govindan, 2018). These problems impede construction firms to implement sustainable consumption and production (SCP) strategies. To alleviate these problems, eco-innovation has received widespread attention from the construction firms for achieving sustainable development and thereby gaining competitive advantages (Cai \& Li, 2018). However, practical methods that can be adopted by construction firms to understand and apply the theoretical framework of eco-innovation and thereby achieve SCP are still lacking.

Eco-innovation has emerged as a new business value in the construction sector recently. Kiefer, Carrillo-Hermosilla, Del Río, and Callealta Barroso (2017) indicated that eco-innovation could narrow the influence of production and consumption activities on the environment. It is also believed that eco-innovation is a critical player to produce a more sustainable economy and society where both competitiveness and sustainability can be maintained. Eco-innovation can provide environmental, economic and social benefits, create a win-win situation, and improve sustainable performance (Wu, Liao, Chen, Lin, \& Tsai, 2016). In addition, Michaelis (2003) emphasized that eco-innovation not only allows firms to incorporate into the conventional business model with environmental concern but also brings more sustainable consumption patterns. According to Machiba (2010), eco-innovation leads firms towards sustainable production by raising efficiency in resources and green growth. Dočekalová, Doubravský, Dohnal, and Kocmanová (2017) stated that corporate governance is positively related to sustainable performance. Moreover, Carrillo-Hermosilla, Del González, and Könnölä (2009) proposed eco-innovation is applied across the business from the strategy and business model via a variety of operational activities (e.g., design, production, purchasing, and marketing). In short, eco-innovation affects sustainable consumption and production from multiple perspectives.

Even though some studies have demonstrated that SCP has an aggregate and multidimensional characteristic (Tseng, Chiu, \& Liang, 2018; Govindan, 2018), a comprehensive analysis of SCP undertaking its multidimensional nature has not been investigated. Previous studies have explored SCP through literature reviews, basic statistical methods and in-depth interviews (Geels, McMeekin, Mylan, \& Southerton, 2015; Dubey et al., 2016; Thongplew, Spaargaren, \& van Koppen, 2017), but these studies focused primarily on the small-scale industries and ignored the correlation between eco-innovation and SCP. Therefore, to seek the drivers to SCP adoption in the construction industry, quantitative analysis should be conducted with the help of experts' opinion in order to identify the importance of each influencing factor. In this study, a fuzzy decision-making trial and evaluation laboratory (FDEMATEL) method was adopted in this paper to understand and evaluate the perfor- 
mance of SCP based on an eco-innovative framework. The fuzzy set theory was utilized to transfer the experts' linguistic preferences into quantitative measurements and address the ambiguity in the decision-making process (Keršuliene \& Turskis, 2011; Zhang \& Guan, 2018). Furthermore, the DEMATEL method was used to analyze both the causal relationship and the impact of the target system's factors (Pourahmad et al., 2015). Then, the influence of the factors was presented using a visual diagram (Wu, Liao, Tseng, \& Chiu, 2015).

Thus, the objectives of the study are to find SCP factors through accurately evaluating their performance and to provide precise guidelines to the construction firms for eco-innovative applications. First, this study has developed a novel measure for evaluating SCP in the construction industry. Second, the proposed method can help firms assess performance toward achieving sustainability. Third, our work can provide precise guidelines for the construction firms on the quintessential eco-activities for attaining SCP in the production process.

The organization of this paper is presented as follows: Section 2 gives a literature review on SCP and eco-innovation. Section 3 introduces the hybrid method and the analytical steps utilized in this work, while Section 4 shows the case study and the empirical results. Then, the implications regarding the theoretical and managerial perspectives are presented in Section 5. Finally, Section 6 provides conclusions, contributions, limitations, and prospects of the study.

\section{Literature review}

The relevant literature on SCP and eco-innovation is shown in this section. The research gaps are also discussed.

\subsection{Sustainable consumption and production (SCP)}

Ongoing demand for the transformation of conventional approaches towards SCP in the construction sector plays an essential role in implementing sustainable practices in the whole world (Luthra, Govindan, \& Mangla, 2017; Govindan, 2018). The initial concept of SCP was proposed during the World Summit on Sustainable Development in 1992, focusing the research to tackle sustainability challenges (Akenji \& Bengtsson, 2014). SCP was defined as "the use of services and related products, which respond to basic needs and bring a better quality of life while minimizing the use of natural resources and toxic materials as well as the emissions of waste and pollutants over the life cycle of the service or product so as not to jeopardize the needs of further generations" (Oslo Symposium, 1994). During the World Summit on Sustainable Development in 2002, the SCP concept was recognized as a fundamental goal for achieving sustainable development (Jackson, 2006). At the conference Rio+20 in 2012, world leaders asserted strongly again on the commitment to reach SCP by adopting a 10-year framework of SCP programs (Akenji \& Bengtsson, 2014; Govindan, 2018).

Previous studies offer fluid and scattered analyses of SCP; hence, exploring SCP within a unified framework is critical to realize real-world applications (Bai, Shah, Zhu, \& Sarkis, 2018). Several studies have identified two main instruments: responsible consumption and responsible production (Geels et al., 2015; Liobikienè \& Dagiliūte, 2016). Because the patterns of consumption and production have direct or indirect impacts on resource efficiency, 
environmental pollution, and waste, they influence the pursuit of sustainability (Schinkel \& Spiegel, 2017). SCP can transform environments, economies, as well as societies to realize sustainability for humans (Blok et al., 2015; Luthra et al., 2017). Azapagic, Stamford, Youds, and Barteczko-Hibbert (2016) stated that moving toward SCP should balance a plethora of economic, environmental, and social aspects. Moreover, corporate governance, which can lead firms to accommodate more sustainability practices through making strategies has also been proposed (Aras \& Crowther, 2008; Dočekalová et al., 2017).

Numerous studies have demonstrated the importance of achieving SCP to minimize environmental regulatory pressure, enhance competitiveness, and improve firms' sustainable performance (Stevens, 2010; Wong, Soh, \& Chong, 2016; Tseng \& Tan, 2016). For example, Zhao and Schroeder (2010) summarized existing policies in Asian countries regarding the development of a green economy and concluded that SCP is a comprehensive method to address the global environmental challenge. Blok et al. (2015) conducted an overview of SCP and found that SCP practices can not only promote firm's sustainable development but also promote a balance between the development of global economy and that of political systems. Since the construction industry has been striving to achieve SCP to increase competitiveness, eco-innovation studies are essential to offer viable solutions to improve the sustainable performance of the industry.

\subsection{Eco-innovation}

Kemp and Pearson (2007) defined the eco-innovation as "production, application or exploitation of a good, service, production process, organizational structure, management or business method that is novel to the firm or user and which results, throughout its lifecycle, in a reduction of environmental risk, pollution and the negative impacts of resources use (including energy use) compared to relevant alternatives." Kiefer et al. (2017) summarized previous definitions and stated, "eco-innovations, or innovations which reduce the environmental impact of production and consumption activities, are generally considered key in the transition towards more sustainable economies and societies and help mitigate the traditional dichotomy between competitiveness and sustainability." These definitions demonstrate the involvement of crucial elements for eco-innovation. Eco-innovation is not only an important factor for firms' clean production and their sustainability but also at the core of the promotion of sustainability and "smart growth" (Horbach, 2008).

As a critical driving force, eco-innovation can improve the firm's sustainability performance, and thus its implementation should include diverse practices and initiatives (Wu et al., 2016; Cui, 2017). Hojnik and Ruzzier (2016) analyzed different drivers of eco-innovation and found influential variables, such as demand-pull and cost-saving, as well as internal and international factors. Cui (2017) investigated the driving factors of eco-innovation, such as improving health and safety with green purchasing to enhance business functions in a developing country. Roddis (2018) identified 15 innovation examples at the sector of wind energy in the UK and found that eco-process and eco-organizational innovations were the most sensitive to the institutional and political influences. He also found that eco-product innovations were the most sensitive to supply-side factors. Nevertheless, viable eco-innovations have been applied in various fields and sectors; hence, eco-innovations are diverse as well as 
industry-specific. Therefore, a new set of measures is needed to meet the skills and capabilities of the construction industry.

Bossle, Dutra De Barcellos, Vieira, and Sauvée (2016) investigated why and how firms integrated environmental sustainability with the innovation process and concluded that firms should focus on eco-innovation to be one of the explicit goals of their strategies to boost performance. Wu et al. (2016) explored eco-innovation in dynamic organizational capability when information is incomplete in the lighting industry at Taiwan and found that improving this dynamic organizational capacity of single firms can explore several eco-innovation opportunities in green markets. Additionally, Cai and Li (2018) investigated the relationship between drivers, eco-innovation behaviors, and firm's performance of 442 Chinese firms, and showed that eco-innovation behavior could significantly enhance the environmental performance of a firm. Nevertheless, previous studies demonstrated the correlation between eco-innovation and a firm's performance but did not propose an effective method for assessing their relationship. This study presents a hybrid approach to evaluate eco-innovation performance and identify specific SCP factors to achieve sustainability.

\subsection{The research gaps}

For the better understanding of analytical frameworks, prior research has utilized qualitative methods, case studies as well as literature reviews to explore SCP (Seyfang, 2004; Berg, 2011; Dubey et al., 2016). Pallaro, Subramanian, Abdulrahman, and Liu (2015) applied an integrated review framework based on 42 relevant articles published between 2004 and 2014 to understand the sustainability challenges and drivers in the consumption and production stages. Azapagic et al. (2016) used a novel decision-support framework and case study to test whether achieving SCP needs a systematic approach based on life cycle thinking, as well as integration in economic, environmental, and social aspects. In addition, Luthra et al. (2017) developed a structural model for the evaluation of SCP drivers and improvement of sustainability aspects in the supply chain scenario under the uncertain environment. However, a comprehensive approach to performance evaluation has not been addressed to date.

Previous studies have utilized a variety of methods to explore eco-innovation. For example, Doran and Ryan (2012) conducted an empirical analysis to explore the driving factors of eco-innovation and test whether adopting eco-innovation can improve firms' performance using 2,181 firms as samples. Scarpellini, Valero-Gil, and Portillo-Tarragona (2016) analyzed the determinants of eco-innovation projects through 44 applied cases. Del Río, Carrillo-Hermosilla, Könnölä, and Bleda (2016) developed an integrated framework to explore how the internal factors (e.g., resources, capabilities, and competences) and the external factors (e.g., policies and stakeholders) affect the implementation and development of eco-innovation. These studies all indicated that eco-innovation is a feasible direction towards sustainable development, but few studies explored the sustainability of eco-innovation and SCP. Thus, the link between eco-innovation and SCP remains incomplete.

In this study, we aimed at adopting the fuzzy set theory integrated with decision making trial and evaluation laboratory (DEMATEL) to overcome the aforementioned research gaps. The fuzzy set theory was utilized to transform linguistic preferences into comparable crisp values (Tseng, Lim, Wong, Chen, \& Zhan, 2018). During decision-making procedures, 
decision-makers are often in the uncertain environment due to time pressure, lack of knowledge, limited attention and insufficient information, all of which increase the complexity and contradictions of subjective judgments (Wu, Tseng, Chiu, \& Lim, 2017). Thus, the fuzzy set theory was used to overcome these issues and shift the linguistic preferences to quantitative analysis (Wang, Ma, Wu, Chiu, \& Nathaphan, 2018). Subsequently, DEMATEL was utilized for the determination of the cause and effect relationship between the aspects of SCP and criteria of eco-innovation that enable decision makers to develop long-standing strategies for achieving the desired objectives (Heravi \& Charkhakan, 2014; Kumar \& Dixit, 2018).

\section{Research methodology}

This section presents the proposed measures (shown in Table 1) and the methods utilized in the study.

\subsection{The proposed measures}

Numerous studies confirmed that SCP should involve the economic aspect (A1) (Azapagic et al., 2016). Hence, five criteria of eco-innovation were proposed to enhance the understanding of SCP. Firm's R\&D expenditure (C1) facilitates economic rent, develops technological capabilities, and gains a first-mover advantage, thus contributes to the firm's future performance (Dong, Wang, Jin, Qiao, \& Shi, 2014; R. Wang, F. Wang, Xu, \& Yuan, 2017). Eco-innovation takes advantage of capital and technology, so increasing investments in equipment and technology reformation (C2) can increase the regional green products' productivity and their market share (Hitchens, 1999; Santos, Basso, Kimura, \& Sobreiro, 2015). Access to the existing subsidies and fiscal incentives (C3) can motivate firms to adopt sustainable development practices more actively (Triguero, Moreno-Mondéjar, \& Davia, 2013). Furthermore, controlling capital efficiency $(\mathrm{C} 4)$ plays a vital role in improving corporate performance, profitability and value creation (Hahn \& Figge, 2011; Cui, 2017). The potential for cost savings (C5), such as through the reduction of required input is also the driver of eco-innovation, which can enhance competitiveness (Roddis, 2018).

Eco-innovation can transform the innovation system to build sustainable processes after the environmental aspect (A2) is brought into discussions. Life cycle assessment (C6) is selected as a valuable tool for the industry's environmental sustainability (Sanni, 2018). Compliance with environmental regulations (C7) is found as the most cited factor along with normative pressure and the efficiency's need (Bossle et al., 2016; Hojnik \& Ruzzier, 2016). Firms play a dramatic role as the largest consumers of natural resources and the main factors causing environmental degradation (Cohen \& Winn, 2007), so strengthening management of natural resources and waste (C8) and adoption of clean technologies (C9) have a direct influence on relieving environmental pressures (Zollo, Cennamo, \& Neumann, 2013; de Jesus \& Mendonça, 2018). Eco-labels and environmental certification (C10) can improve firms' environmental awareness and market recognition as intangible assets (Segarra-Oña, PeiróSignes, \& Cervelló-Royo, 2015).

Firms usually focus on environmental and economic factors, often neglecting vital social aspect (A3), which is an essential element for achieving SCP (Yiftachel \& Hedgcock, 1993; 
Azapagic et al., 2016). Corporate reputation (C11) has been mentioned as a corporate asset that adds value to the actual worth of a firm and can increase firm's competitiveness (Hong, Shin, \& Kim, 2016; Hojnik \& Ruzzier, 2016). Corporate social responsibility (CSR) (C12) motivates firms to implement eco-innovation, and the adoption of CSR may reflect the firm's strategy reinforcement or reorientation by signaling a commitment to green issues and establishing the firm's green image (Kesidou \& Demirel, 2012). Increased competitive pressure (C13) are forcing firms to continuously develop and innovate to improve the competitiveness of green products, such as product design and quality, technology service, and reliability (Hojnik \& Ruzzier, 2016). Moreover, access to external knowledge (C14) and staff training (C15) can enhance absorptive capacity and competitiveness of firms as they help generate and consolidate new knowledge and skills, which could help engender innovations (Martin, McNeill, \& Warren-Smith, 2013; Sanni, 2018).

Corporate governance (A4) is fundamental to the operation of any firms and has a significant impact on achieving sustainability (Aras \& Crowther, 2008). Abilities to perform organizational adjustments (C16) refer to the allocation of resources according to the task, and to control, motivate, and coordinate the process of group activities so that they can be integrated to achieve organizational goals (Wu et al., 2016). Product orientation (C17) can assist firms to concentrate on the increase of the products' quality or number, thus increasing market share (Segarra-Oña et al., 2015). Creating an effective and functional team (C18) enables firms to be innovative and flexible while maintaining a high level of performance (Latif \& Williams, 2017; Ociepa-Kubicka \& Pachura, 2017). Cooperation with external partners (C19) helps cross-fertilization of knowledge and sources, enabling the integration of several innovative abilities to produce novel and useful products and services (Bönte \& Dienes, 2013; Lin, 2017). In addition, strategic planning (C20) is to define its strategy or direction and make decisions on the allocation of its resources to achieve the strategy (García-Pozo, Sánchez-Ollero, \& Marchante-Lara, 2015).

Sustainable consumption (A5) has emerged as a critical priority area in research and decision-making associated with sustainable development (Liu, Valentine, Vanderbeck, McQuaid, \& Diprose, 2018). Providing eco-demand for the customer (C21) fulfills not only the physical and social needs for customers but also the consumption of green products and services (Horbach, Rammer, \& Rennings, 2012; Tseng \& Tan, 2016). Consumer participation (C22) (e.g., reviewing the consumers' views) can help assure the transparency, credibility as well as information provision's robustness (Horbach et al., 2012). Enhance communication (C23) can increase an in-depth comprehension of the responsibilities and obligations of participants so that the firm's strategy can be effectively implemented (Jones, Stanton, \& Harrison, 2001). Improving eco-efficiency (C24) and reuse and recycling (C25) can decrease the consumption of resources, energy, and the environmental load during production or operation of a firm (Faucheux \& Nicolaï, 2011; F. Yang \& M. Yang, 2015).

Sustainable production (A6) is becoming increasingly vital for production and operation of firms, mainly because production is the source of many environmental and ecological problems (Luo et al., 2017). From the beginning to the end of a project, pollution control and prevention (C26) and utilizing sustainable operational processes (C27) play a key role in reducing environmental impacts and achieving clean production (Wu et al., 2015). Eco- 
design strategies (C28) usually recommend using cleaner or more appropriate natural materials to reduce environmental risks and improve product performance during production (Wang, Chan, Lee, \& Li, 2015; Shi et al., 2017). Using eco-materials and clean energy (C29) can help reduce the environmental costs of products during their extraction, manufacturing, use, and end-of-life (Triguero et al., 2013). The number of patent applications (C30) reflects the firm's innovation and technological capabilities and promotes the production and operation (Dong et al., 2014).

Table 1. Evaluation aspects and criteria for SCP

\begin{tabular}{|c|c|c|c|}
\hline \multicolumn{2}{|r|}{ Aspects } & \multicolumn{2}{|r|}{ Criteria } \\
\hline \multirow{5}{*}{ A1 } & \multirow{5}{*}{ Economic } & $\mathrm{C} 1$ & Firm's R\&D expenditure \\
\hline & & $\mathrm{C} 2$ & Investments in equipment and technology reformation \\
\hline & & $\mathrm{C} 3$ & Access to existing subsidies and fiscal incentives \\
\hline & & $\mathrm{C} 4$ & Controlling capital efficiency \\
\hline & & C5 & The potential for cost saving \\
\hline \multirow{5}{*}{ A2 } & \multirow{5}{*}{ Environmental } & C6 & Life cycle assessment \\
\hline & & C7 & Compliance with environmental regulations \\
\hline & & $\mathrm{C} 8$ & Strengthen management of natural resources and waste \\
\hline & & C9 & Adoption of clean technologies \\
\hline & & $\mathrm{C} 10$ & Eco-labels and environmental certification \\
\hline \multirow{5}{*}{ A3 } & \multirow{5}{*}{ Social } & $\mathrm{C} 11$ & Corporate reputation \\
\hline & & $\mathrm{C} 12$ & Corporate social responsibility \\
\hline & & $\mathrm{C} 13$ & Increased competition pressures \\
\hline & & C14 & Access to external knowledge \\
\hline & & C15 & Staff training \\
\hline \multirow{5}{*}{ A4 } & \multirow{5}{*}{ Corporate governance } & C16 & Abilities to perform organizational adjustments \\
\hline & & $\mathrm{C} 17$ & Product orientation \\
\hline & & $\mathrm{C} 18$ & Creating an effective and functional team \\
\hline & & C19 & Cooperation with external partners \\
\hline & & $\mathrm{C} 20$ & Strategic planning \\
\hline \multirow{5}{*}{ A5 } & \multirow{5}{*}{ Sustainable consumption } & $\mathrm{C} 21$ & Providing eco-demand for customer \\
\hline & & $\mathrm{C} 22$ & Consumer participation \\
\hline & & $\mathrm{C} 23$ & Enhance communication \\
\hline & & $\mathrm{C} 24$ & Improving eco-efficiency \\
\hline & & $\mathrm{C} 25$ & Reuse and recycling \\
\hline \multirow{5}{*}{ A6 } & \multirow{5}{*}{ Sustainable production } & $\mathrm{C} 26$ & Pollution control and prevention \\
\hline & & $\mathrm{C} 27$ & Utilizing sustainable operational processes \\
\hline & & $\mathrm{C} 28$ & Eco-design strategies \\
\hline & & $\mathrm{C} 29$ & Using eco-materials and clean energy \\
\hline & & C30 & The number of patent applications \\
\hline
\end{tabular}




\subsection{The fuzzy set theory}

During the decision-making process, experts usually make judgments based on their experience and expertise and evaluate the factors' relationships using linguistic preferences (Table 2). The qualitative expression of experts' subjective preferences is affected by uncertainty. For example, the terms "excellent," "very good," "high influence" expressed by experts include vagueness or fuzziness. The fuzzy set theory provides an objective way of taking the uncertainty of judgment into account, which can be used to handle such problems (Jang, Lee, \& Han, 2018).

Table 2. Linguistic Scales for Corresponding TFNs proposed by Wu et al. (2015)

\begin{tabular}{|c|l|c|}
\hline Scales & \multicolumn{1}{|c|}{ Linguistic Preferences } & Corresponding Triangular Fuzzy Numbers \\
\hline 1 & No influence or importance & $(0,0.1,0.3)$ \\
\hline 2 & Very low influence or importance & $(0.1,0.3,0.5)$ \\
\hline 3 & Medium influence or importance & $(0.3,0.5,0.7)$ \\
\hline 4 & High influence or importance & $(0.5,0.7,0.9)$ \\
\hline 5 & Very high influence or importance & $(0.7,0.9,1.0)$ \\
\hline
\end{tabular}

Assuming that there is a universe of discourse $Y=\left\{y_{1}, y_{2}, \ldots, y_{n}\right\}$. Then, fuzzy set $\tilde{Z}$ of $Y$ is adopted to represent a set of ordered pairs $\left\{\left(y_{1}, f_{\widetilde{Z}}\left(y_{1}\right)\right),\left(y_{2}, f_{\widetilde{Z}}\left(y_{2}\right)\right), \ldots,\left(y_{n}, f_{\widetilde{Z}}\left(y_{n}\right)\right)\right\}$, where $f_{\widetilde{Z}}: Y \rightarrow[0,1]$ represents the membership function of $\widetilde{Z}$, and $f_{\widetilde{Z}}\left(y_{i}\right)$ represents the membership degree of $y_{i}$ in $\widetilde{Z}$. This study was based on definitions and notations of the fuzzy set theory from Lin, Tseng, Chen, and Chiu (2011) and Wu et al. (2015). Some definitions are as follows:

Definition 1. Whether $Y$ is an infinite or finite set affects the fuzzy set $\widetilde{Z}$ expressed as $\widetilde{Z}_{i}$ or $\widetilde{Z}_{f}$

$$
\left\{\begin{array}{l}
\widetilde{Z}_{i}=\frac{\int_{y} f_{\widetilde{Z}}\left(y_{i}\right)}{y}, y \in Y, \text { when } Y \text { is an infinite set } \\
\widetilde{Z}_{f}=\frac{\sum_{i} f_{\widetilde{Z}}\left(y_{i}\right)}{\left(y_{i}\right)}, y_{i} \in Y, \text { when } Y \text { is a finite set }
\end{array}\right.
$$

Definition 2. If the fuzzy set $\widetilde{Z}$ of universe of discourse $Y$ is normal, the corresponding membership function $f_{\widetilde{Z}}(y)$ must satisfy $\max f_{\widetilde{Z}}(y)=1$.

Definition 3. The fuzzy number is a fuzzy subset in the universe of discourse $Y$, and it is normal rather than convex.

Definition 4. The fuzzy $\alpha-$ cut $\widetilde{Z}_{\alpha}$ and strong $\alpha-$ cut $\widetilde{Z}_{\alpha+}$ of the fuzzy set $\tilde{Z}$ in the universe of discourse $Y$ is defined by

$$
\begin{aligned}
& \widetilde{Z}_{\alpha}=\left\{y_{i} \mid f_{\widetilde{Z}}\left(y_{i}\right) \geq \alpha, y_{i} \in Y\right\}, \text { where } \alpha \in[0,1] ; \\
& \widetilde{Z}_{\alpha+}=\left\{y_{i} \mid f_{\widetilde{Z}}\left(y_{i}\right) \geq \alpha, y_{i} \in Y\right\}, \text { where } \alpha \in[0,1] .
\end{aligned}
$$


Definition 5. If the fuzzy set $\widetilde{Z}$ of the universe of discourse $Y$ is convex and each $\widetilde{Z}_{\alpha}$ is convex, $\widetilde{Z}_{\alpha}$ is a close internal b. This can be written as

$$
\widetilde{Z}_{\alpha}=\left[\beta_{1}^{\alpha}, \beta_{2}^{\alpha}\right] \text {, where } \alpha \in[0,1] \text {. }
$$

Definition 6. A triangular fuzzy number (TFN) is defined by a triplet $\left(l_{1}, m_{2}, r_{3}\right)$. The membership function of the fuzzy number $\widetilde{Z}$ is written as

$$
f_{\widetilde{Z}}(y)=\left\{\begin{array}{l}
0, y \prec l_{1} \\
\left(y-l_{1}\right) /\left(m_{2}-l_{1}\right), l_{1} \leq y \leq m_{2} \\
\left(r_{3}-y\right) /\left(r_{3}-m_{2}\right), m_{2} \leq y \leq r_{3} \\
0, y \succ r_{3}
\end{array} .\right.
$$

Assuming that the experts' committee consists of $\mathrm{h}$ respondents, and the linguistic scale of their judgments should be transferred to $\widetilde{T}_{i j}^{h}=\left(t_{1 i j}^{h}, t_{2 i j}^{h}, t_{3 i j}^{h}\right)$, which means the degree to which attribute $i$ influences attribute $j$ according to the $h^{\text {th }}$ response. However, these fuzzy numbers still have the incomparable feature. The defuzzification process requires that the triangular fuzzy numbers must be transformed into crisp values, and this study adopted max-min to conduct the process. The max-min normalization process is displayed as follows.

Normalization:

$$
\begin{aligned}
& y t_{1 i j}^{h}=\left(t_{1 i j}^{h}-\min t_{1 i j}^{h}\right) / \Delta_{\min }^{\max } ; \\
& y t_{2 i j}^{h}=\left(t_{2 i j}^{h}-\min t_{2 i j}^{h}\right) / \Delta_{\min }^{\max } ; \\
& y t_{3 i j}^{h}=\left(t_{3 i j}^{h}-\min t_{3 i j}^{h}\right) / \Delta_{\min }^{\max },
\end{aligned}
$$

where $\Delta_{\min }^{\max }=\max t_{3 i j}^{h}-\min t_{1 i j}^{h}$.

Computing left (lq) and right (rq) normalized values:

$$
\begin{aligned}
& y l q_{i j}^{h}=y t_{2 i j}^{h} /\left(1+y t_{2 i j}^{h}-y t_{1 i j}^{h}\right) ; \\
& y r q_{i j}^{h}=y t_{3 i j}^{h} /\left(1+y t_{3 i j}^{h}-y t_{2 i j}^{h}\right) .
\end{aligned}
$$

Developing total normalized crisp values:

$$
y_{i j}^{h}=\left[y l q_{i j}^{h}\left(1-l q_{i j}^{h}\right)+\left(y r q_{i j}^{h}\right)^{2}\right] /\left(1-y l q_{i j}^{h}+y r q_{i j}^{h}\right) .
$$

Calculating the crisp values:

$$
w_{i j}^{h}=\min t_{1 i j}^{h}+y_{i j}^{h} \Delta_{\min }^{\max } .
$$

The final step of the process is aggregating the crisp values:

$$
\tilde{w}_{i j}=\sum_{1}^{h} w_{i j}^{h} / h, h=1,2, \cdots, n .
$$




\subsection{The DEMATEL method}

As a practical and useful approach, DEMATEL method can display the complex relationship through cause and effect diagram (Pourahmad et al., 2015). Obtaining the diagram should begin with the evaluation from the expert group. After the crisp aggregating crisp values are calculated using the fuzzy set theory, then the following progress is used to generate the cause and effect diagram.

Arranging these crisp values $\tilde{w}_{i j}$ into direct relation matrix $M=\left[\tilde{w}_{i j}\right]_{n \times n}$, then according to direct relation matrix $M$, the normalized direct relation matrix $\bar{M}$ is obtained using Eqs (6) and (7):

$$
\begin{gathered}
\bar{M}=p \times M ; \\
p=1 / \max _{1 \leq i \leq n} \sum_{j=1}^{n} \tilde{w}_{i j} .
\end{gathered}
$$

Subsequently, the normalized direct relation matrix $\bar{M}$ should integrate with identity matrix $O$ to acquire the total relation matrix $K$ :

$$
K=\bar{M} \times(O-\bar{M})^{-1} .
$$

Lastly, based on the total relation matrix $K$, the sum of rows $\left(V^{d}\right)$ and columns $V^{r}$ are calculated by the following equations:

$$
\begin{aligned}
K & =\left[k_{i j}\right]_{n \times n}, i, j=1,2, \cdots, n ; \\
V^{d} & =\left[\sum_{j=1}^{n} k_{i j}\right]_{1 \times n}=\left[k_{j}\right]_{1 \times n} ; \\
V^{r} & =\left[\sum_{i=1}^{n} k_{i j}\right]_{n \times 1}=\left[k_{i}\right]_{n \times 1} .
\end{aligned}
$$

Therefore, $\left(V^{d}-V^{r}\right)$ and $\left(V^{d}+V^{r}\right)$ are the vertical and horizontal axis in the cause and effect diagram, respectively. If $\left(V^{d}-V^{r}\right)$ is negative, the factors are deemed effect, and conversely, the factors are cause. Moreover, $\left(V^{d}+V^{r}\right)$ shows the importance of the factors.

\subsection{The proposed analytical steps}

1. The proposed measurements were developed from a relatively thorough literature review, and by consulting the experts' committee. This study has formed a two-member committee, which consisted of industry experts and academic professors to confirm the reliability of the measurements. The form of communication was mainly through face-to-face interviews or by phone.

2. Subsequently, each expert used survey instruments to make judgments on the importance and performance of the measurements identified above in linguistic terms individually based on their rich knowledge and experience in the industry. After careful consideration and judgment, the experts provided feedback on the questionnaire.

3. Transforming the linguistic preferences into crisp values were performed. After collecting the experts' response, the linguistic preferences should be transferred into triangular fuzzy numbers first based on Table 2 . Then, the fuzzy numbers were converted into 
crisp values. Acquiring crisp values $\tilde{w}_{i j}$ for the defuzzification and aggregation process was performed using Eqs (1)-(5).

4. Cause and effect diagram through DEMATEL was created. The crisp values were composed into the initial direct relation matrix, and the normalized direct relation matrix was acquired according to Eqs (6)-(8). Subsequently, the cause and effect diagram through Eqs (9)-(11) was produced. The procedures of the analytical steps are shown in Figure 1.

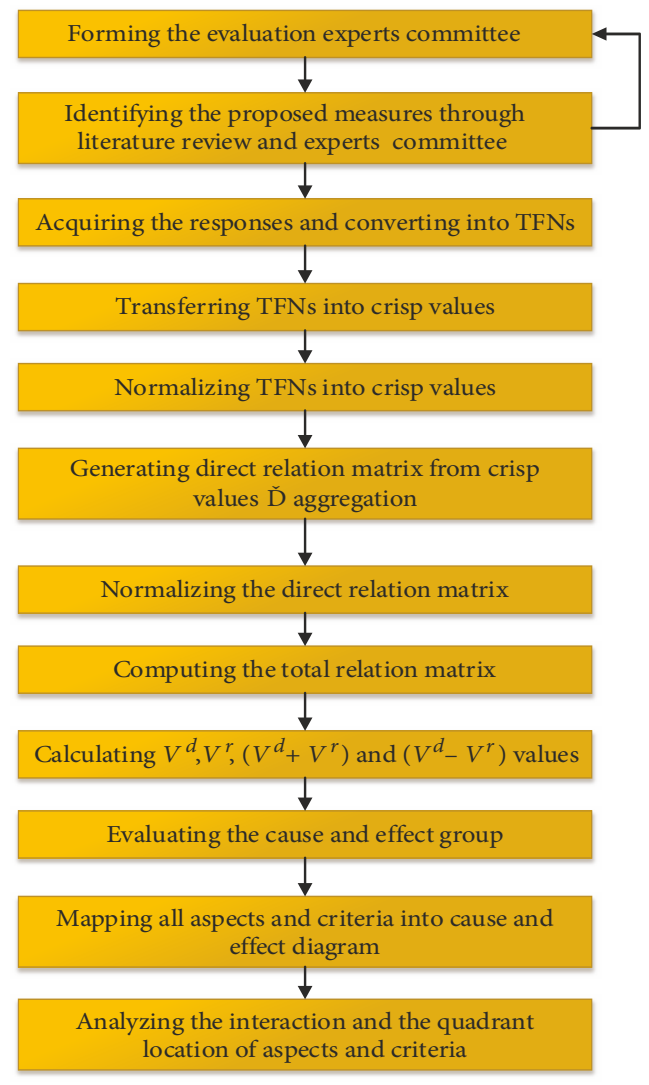

Figure 1. Flowchart of fuzzy DEMATEL evaluation

\section{Results}

\subsection{Case information}

The case firm (Firm L) is one of the largest property developers in China that was ranked in the Fortune Global 500 in 2016. Firm L does business in a variety of areas, such as property management and investment, decoration, and hotel development and management. In the downturn Chinese property industry, Firm $L$ has gone retrograde. The sales volume and area of the contracts have increased substantially, ranking the first in the industry. Unlike other firms that focus on big cities, Firm L's strategies and focus of work concentrate on small and medium-sized cities, with investments across the country. However, due to widespread 
investment scope, Firm L is facing financial pressure and can only produce quickly to return the funds. Therefore, the phenomenon of unsustainable consumption and production occurs frequently. Firm L seeks to adopt eco-innovation toward achieving SCP.

Firm L has realized that SCP can help save costs, acquire recognition and increase competitiveness in the competitive market environment, and positively made huge investments and considerable resources to change consumption and production patterns toward sustainability. However, there is still limited research on the objective evaluation of eco-innovation and its mechanism for assessing SCP. Many firms still use empirical and traditional quantitative approaches to evaluate performance, but encounter difficulties in the identification of SCP in the rapidly changing competitive market. Therefore, this study utilizes FDEMATEL to assist Firm L in assessing its current eco-innovation performance and identifying SCP scheme. The empirical results are presented in the next sub-section and provide guidelines to Firm L for the implementation.

\subsection{Empirical results}

1. This study proposes six aspects and thirty criteria (as shown in Table 1) which were first identified from the literature to utilize the eco-innovative framework to explore and implement SCP in the construction industry. Then, they were discussed and confirmed by the expert group, which is recommended by case firm. The expert group with fifteen members consisted of four professors with at least ten years of industry consulting experience, and industry experts including four general managers, three assistant general managers, two senior managers, and two senior engineers, all of whom had at least eight-year experience in the construction industry. In addition, the expert group members have long cooperated with or provided consulting services to case firms, and these experts are committed to developing innovative practices in the construction industry. The relevant information of experts is shown in Table 3.

2. Experts made pair-wise comparisons among the final determined aspects and criteria using a linguistic scale provided in Table 2 . Table 4 shows the criteria sample assessment from Expert 1.

3. The experts' judgments were converted into TFNs and normalized to crisp numbers by using Eqs (1)-(4) to develop the initial direct relation matrix; then, the 15 experts' feedback was aggregated into the subjective judgment adopting Eq. (5) to obtain the crisp values $\widetilde{w}_{i j}$. Table 5 shows the fuzzy initial direct relation matrix of the criteria.

4. The normalized direct relation matrix was achieved using Eqs (6)-(7). The total direct relation matrix of the criteria was acquired using Eq. (8), which is shown in Table 6. The $\left(V^{d}+V^{r}\right)$ and $\left(V^{d}-V^{r}\right)$ were identified utilizing Eqs (9)-(11) as shown in Tables 7 and 8 . The sum of rows and columns of the total direct relation matrix generated vectors $V^{d}$ and $V^{r}$, respectively. An aspect or criteria is grouped into a member of the cause group if $\left(V^{d}-V^{r}\right)$ is positive, otherwise, in the case of its negative value, the aspect or criteria attributes it to the effect group. $\left(V^{d}+V^{r}\right)$, which is the horizontal axis termed "Prominence" stands for the factors' importance; similarly, $\left(V^{d}-V^{r}\right)$, which is the vertical axis named "Relation" formulates the factors into a cause group. Hence, the cause and effect diagram is mapped by the values of $\left(V^{d}+V^{r}, V^{d}-V^{r}\right)$, as shown in Figures 2 and 3. 
Table 3. The experts' information

\begin{tabular}{|l|l|l|l|l|c|}
\hline & Age & Gender & & Torking Unit & $\begin{array}{c}\text { Industry consulting } \\
\text { Experience or Working } \\
\text { Experience }\end{array}$ \\
\hline Expert 1 & 45 & Male & Professor & University & 13 years \\
\hline Expert 2 & 44 & Male & Professor & University & 11 years \\
\hline Expert 3 & 52 & Female & Professor & University & 20 years \\
\hline Expert 4 & 50 & Male & Professor & University & 17 years \\
\hline Expert 5 & 35 & Male & General managers & Construction unit & 9 years \\
\hline Expert 6 & 33 & Female & General managers & Construction unit & 8 years \\
\hline Expert 7 & 39 & Male & General managers & Construction unit & 14 years \\
\hline Expert 8 & 33 & Male & General managers & Construction unit & 9 years \\
\hline Expert 9 & 32 & Male & Assistant general managers & Construction unit & 8 years \\
\hline Expert 10 & 34 & Male & Assistant general managers & Construction unit & 10 years \\
\hline Expert 11 & 31 & Female & Assistant general managers & Construction unit & 8 years \\
\hline Expert 12 & 40 & Male & Senior managers & Construction unit & 15 years \\
\hline Expert 13 & 42 & Male & Senior managers & Construction unit & 13 years \\
\hline Expert 14 & 48 & Male & Senior engineers & Construction unit & 21 years \\
\hline Expert 15 & 39 & Male & Senior engineers & Construction unit & 11 years \\
\hline
\end{tabular}

We separated the influence among the SCP aspects and within the criteria of eco-innovation. Among the six core aspects of SCP, the results revealed that A2 and A5 are the driving factors for SCP because the values of $\left(V^{d}+V^{r}, V^{d}-V^{r}\right)$ are positive. It means that they are the major players in achieving SCP for construction firms. A4, A6, and A1 represent the core attributes. Although their impact is not as significant as A2 and A5, they are important for the improvement. In addition, A3 denotes the voluntary attribute which is not essential to the firm, although its impact is high. To this end, different factors' priority is in the order of A2, A5, A4, A6, A1, and A3.

Moreover, within the criteria of eco-innovation, nine decisive criteria that can assist firms to utilize eco-innovation and achieve SCP effectively fall into the first quadrant in Figure 2. We identified C6, C10, and C24 as the driving factors for SCP since they are endowed with greater influence compared to other criteria. Moreover, C7, C8, C9, C21, and C25 are ranked in the core attributes quadrant, which constitutes the basic requirement for improvement, though this improvement process should first modify the driving factors.

In summary, the results indicated that the environment (A2) and sustainable consumption (A5) are the most important aspects for the construction firms to implement SCP. In the meantime, life cycle assessment (C6) and eco-labels and environmental certification (C10) are the important driving factors under A2. Improving eco-efficiency (C24) is also an important driving factor under A5. Corporate governance (A4), sustainable production (A6), and economic (A1) aspects are the core issues that should be evaluated. Similarly, C19, C17, $\mathrm{C} 26, \mathrm{C} 30, \mathrm{C} 2$, and $\mathrm{C} 1$ are the corresponding driving factors that can help solve the issues or challenges encountered during SCP. 


\begin{tabular}{|c|c|c|c|c|c|c|c|c|c|c|c|c|c|c|c|c|c|c|c|c|c|c|c|c|c|c|c|c|c|c|}
\hline 仓ิ & 2 & 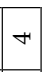 & $m$ & + & $m$ & N & + & $\sim$ & $r$ & $N$ & - & -1 & r & 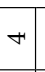 & $m$ & - & $\sim$ & 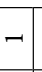 & $m$. & 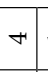 & $\neg$ & & & +1 & +0 & & $m$ & $m$ & & 0 \\
\hline ปิ & s & $m$ & in & $m$ & H & +1 & in & + & F & $F$ & $N$ & $v$ & $m$ & $m$ & $m$ & $\sim$ & + & $m$ & $\sim$ & $F$ & $\sim$ & $N$ & $\sim$ & $m$. & + & H & + & +0 & 0 & $N$ \\
\hline లి & + & $m$ & 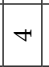 & $m$ & H & in & in & $m$ & $m$ & $F$ & $\sim$ & + & + & $N$ & $\sim$ & $N$ & in & $m$ & $\sim$ & in & $v$ & $N$ & $\sim$ & $H$ & + & 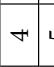 & in & 0. & $m$ & $N$ \\
\hline$\widehat{\mathcal{U}}$ & + & + & + & + & H & +1 & + & + & in & $m$ & $\sim$ & $N$ & $\sim$ & $N$ & in & $N$ & + & in & $m$ & $m$ & 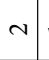 & -1 & -1 & in & + & $m$ & 0 & 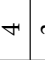 & $m$ & 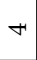 \\
\hline లు & +1 & in & +1 & $m$ & $m$ & in & in & in & in & $m$ & $N$ & $m$ & $n$ & $v$ & $\nabla$ & $\sim$ & + & + & $m$ & $m$ & $\sim$ & $N$ & $\sim$ & H & in & 0 & $r$ & +1 & $n$ & $N$ \\
\hline$\stackrel{\widetilde{U}}{\mathrm{U}}$ & +1 & in & $+r$ & + & in & +1 & + & in & $m$ & $\sim$ & $\sim$ & $m$ & $m$ & + & $\nabla$ & $\sim$ & + & + & $m$ & $m$ & $\sim$ & $N$ & -1 & H & 0 . & $A 1$ & + & + & + & $m$ \\
\hline$\stackrel{\Delta}{U}$ & +1 & in & $\sim$ & + & $m$ & 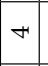 & $m$ & + & $r$ & $m$ & $m$ & $m$ & $m$ & 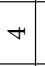 & + & $m$ & $m$ & + & $\sim$ & $m$ & $\sim$ & $N$ & -1 & 0 & in & +1 & +1 & in & + & $m$ \\
\hline$\widetilde{U}$ & -1 & $\sim$ & -1 & $\neg$ & -1 & -1 & $m$ & + & $N$ & $\sim$ & 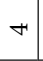 & $v$ & $\sim$ & -1 & + & $N$ & - & $m$ & - & - & $H$ & in & 0 & $\sim$ & $\sim$ & $m-$ & $\rightarrow$ & $m$ & $N$ & - \\
\hline ปิ & $\sim$ & -7 & -1 & -1 & $\sim$ & $\infty$ & $\sim$ & + & $N$ & -1 & $m$ & $\sim$ & $N$ & -1 & $\sim$ & $\neg$ & $m$ & $N$ & $\neg$ & $v$ & in & 0 & + & $\sim$ & $N$ & $m-$ & $\rightarrow$ & $m$ & $m$ & - \\
\hline $\overrightarrow{\mathcal{U}}$ & $\sim$ & $m$ & -1 & -1 & $m$ & $r$ & $\sim$ & $m$ & $m$ & $m$ & $m$ & -1 & $\sim$ & $\neg$ & $\nabla$ & $\neg$ & in & $\sim$ & $\sim$ & $m$ & 0 . & 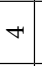 & $m$ & H & $N$ & H & $m$ & $m$ & $m$ & $\sim$ \\
\hline ปิ & $m$ & $m$ & 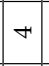 & $\sim$ & $m$ & 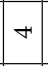 & + & $m$ & $N$ & $F$ & $\sim$ & $F$ & + & $N$ & $m$ & $m$ & in & $m$ & $m$ & 0 & $m$ & $m$ & $\sim$ & $m$ & $m$ & $m$. & $m$ & in & $m$ & $m$ \\
\hline$\stackrel{\vec{u}}{ }$ & -1 & $m$ & $\sim$ & $m$ & $r$ & $\sim$ & $m$ & $N$ & $\sim$ & $+r$ & $m$ & $m$ & in & $m$ & + & + & + & + & 0 & $m$ & $v$ & $N$ & $\sim$ & $\sim$ & $N$ & a & $N$ & $m$ & $N$ & $m$ \\
\hline$\stackrel{\infty}{u}$ & -1 & $\sim$ & -1 & $m$ & $\sim$ & -1 & $\sim$ & $N$ & - & $m$ & $\sim$ & $v$ & + & $m$ & in & in & -1 & 0 & $m$ & $N$ & $\sim$ & -1 & -1 & $m$ & $N$ & 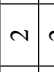 & $\sim$ & $v$ & $\neg$ & - \\
\hline$\vec{u}$ & 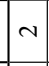 & $\sim$ & $m$ & -1 & -1 & 10 & $m$ & $N$ & $m$ & in & $\sim$ & $N$ & $m$ & $\sim$ & - & - & 0 & $\sim$ & $N$ & in & 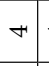 & 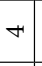 & $\sim$ & $\sim$ & $m$ & $\sim 0$ & $N$ & t & $m$ & $\sim$ \\
\hline $\begin{array}{l}0 \\
U\end{array}$ & $\sim$ & -1 & $\sim$ & $N$ & $\theta$ & -1 & -1 & -1 & $N$ & $\sim$ & $\sim$ & $N$ & in & $F$ & in & 0. & -1 & in & $m$ & $m$ & $v$ & $\neg$ & -1 & $\mathrm{~N} / \mathrm{S}$ & $N$ & $\neg-$ & - & $N$ & $\neg$ & - \\
\hline$\stackrel{10}{0}$ & $F$ & $\sim$ & $\sim$ & $N$ & $\sim$ & $\sim$ & $m$ & $\sim$ & $m$ & $+r$ & $m$ & $m$ & + & in & 0 & $m$ & $N$ & $m$ & $m$ & $m$ & 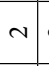 & $N$ & $\sim$ & $m$ & $N$ & $m$ & $m$ & $m$ & $m$ & $H$ \\
\hline$\vec{U}$ & +1 & $\sim$ & $N$ & $\sim$ & $\sim$ & -1 & -1 & -1 & $m$ & 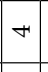 & $\sim$ & $v$ & + & 0 & + & $N$ & $\sim$ & $\sim$ & in & $\sim$ & $\neg$ & -1 & $\neg$ & $-\sigma^{2}$ & $N$ & $v$ & $N$ & $N$ & $N$ & in \\
\hline$\stackrel{m}{u}$ & $N$ & $m$ & $\sim$ & $m$ & $\sim$ & $\sim$ & $\sim$ & $\sim$ & $m$ & 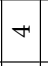 & $\sim$ & $m$ & 0 & $m$ & + & $\sim$ & $m$ & $m$ & $r$ & $v$ & $\sim$ & $\sim$ & - & $m$ & $m$ & $m$ & $m$ & m & + & $r$ \\
\hline$\tilde{U}$ & -1 & $\sim$ & -1 & -1 & - & $\sim$ & $m$ & $m$ & $N$ & $\sim$ & $+r$ & 0 & -1 & $\rightarrow$ & $\neg$ & $\neg$ & $\sim$ & -1 & $\neg$ & $v$ & - & $m$ & $m$ & $m$. & 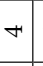 & $r$ & $m$ & 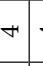 & + & - \\
\hline $\bar{u}$ & $\mathrm{v}$ & $H$ & -1 & -1 & - & $\sim$ & in & + & in & in & 0 & in & - & - & - & - & $v$ & $N$ & $\neg$ & v & $m$ & $m$ & $m$ & $m$. & in & in & $m$ & $m$ & in & - \\
\hline$\stackrel{\circ}{0}$ & $m$ & 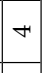 & $\sim$ & $\sim$ & $m$ & 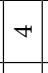 & + & in & in & 0 & $m$ & $\sim$ & 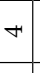 & $m$ & $m$ & - & + & -1 & - & 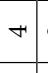 & $m$. & -1 & $\neg$ & $m$ & + & $r$ & 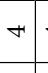 & $r$ & $r$ & $m$ \\
\hline 8 & $r$ & 10 & in & $m$ & 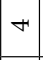 & $m$ & + & 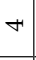 & $b$ & $m$ & $\sim$ & $\psi$ & $m$ & + & $m$ & $\mathrm{~N}$ & + & $\sim$ & $\sim$ & 1 & H & $\sim$ & $\sim$ & $\checkmark$ & $\psi$ & in & $\psi$ & +1 & in & $\sim$ \\
\hline$\cup^{\infty}$ & 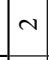 & $H$ & $m$ & $m$ & $m$ & 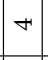 & + & 0 & H & $m$ & $\sim$ & + & $\mathrm{N}$ & $\mathrm{N}$ & H & $\sim$ & $\psi$ & $\sim$ & $\sim$ & $m$ & $m$ & $\sim$ & $\sim$ & $m$. & in & in & $\psi$ & H & in & $\sim$ \\
\hline$\hat{U}$ & $\neg$ & + & $m$ & - & $m$ & $m$ & 0 & + & + & $\sim$ & $m$ & + & $m$ & $\rightarrow$ & $m$ & $\sim$ & $m$ & $N$ & $\sim$ & $m$ & $m$ & 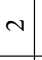 & $m$ & $N$ & + & in & $m$ & + & in & $\sim$ \\
\hline ¿ & 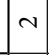 & $m$ & - & $\sim$ & $n$ & 0 & $N$ & $m$ & $r$ & $\sim$ & -1 & $\neg$ & - & $\sim$ & $m$ & $\neg$ & $m$ & - & $\sim$ & $H$ & $\sim$ & N & - & + & + & + & $m$ & 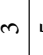 & in & $N$ \\
\hline$\ddot{0}$ & 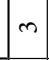 & $\psi$ & $m$ & $\sim$ & 0 & + & - & -1 & + & $\sim$ & -1 & - & - & + & $m$ & $\sim$ & $\sim$ & $\sim$ & $m$ & $m$ & $\sim$ & $v$ & - & + & in & $m$ & 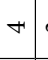 & $m$ & $m$ & + \\
\hline J & 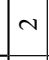 & + & + & 0 & $\sim$ & + & $\sim$ & $m$ & 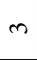 & $m$ & -1 & $\sim$ & 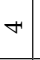 & $N$ & $\sim$ & $m$ & + & 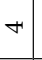 & $\sim$ & $m$ & $\sim$ & - & - & $m$ & r & $m$ & $m$ & $m$ & $H$ & N \\
\hline$\tilde{U}$ & $m$ & $H$ & 0 & $\sim$ & N & $m$ & + & + & $m$ & in & + & $\sim$ & $m$ & $\rightarrow$ & - & $\sim$ & $m$ & - & $\rightarrow$ & $m$ & $\sim$ & - & - & $m$ & $m$ & + & $m$ & $m$ & $H$ & $m$ \\
\hline U & 0 & 0 & $F$ & + & 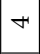 & $m$ & $m$ & $m$ & $r$ & $m$ & $\sim$ & $m$ & in & $H$ & $m$ & $\sim$ & 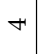 & $m$ & $\sim$ & 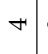 & $\sim$ & - & -1 & $m$ & + & in & + & + & $H$ & in \\
\hline$\vec{U}$ & 0 & $m$ & + & $m$ & $r$ & $m$ & $m$ & - & $r$ & $\theta$ & $\sim$ & $\sim$ & in & $r$ & $m$ & $\neg$ & $m$ & $m$ & $\sim$ & $H$ & N & $\neg$ & -1 & $\sim$ & $m$ & $r$ & $m$ & + & $m$ & in \\
\hline & & 0 & 0 & U & u & 8 & $\hat{0}$ & 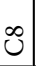 & 0 & $\vec{u}$ & 0 & $\vec{U}$ & c & +1 & & $\begin{array}{l}0 \\
U\end{array}$ & $\overrightarrow{0}$ & ن & $\overrightarrow{\vec{U}}$ & తి & $\vec{\mho}$ & تن & $\tilde{J ે ~}$ & Uు & 8 & స్తు & $\widehat{\widehat{J}}$ & ฮี & U. & లి \\
\hline
\end{tabular}




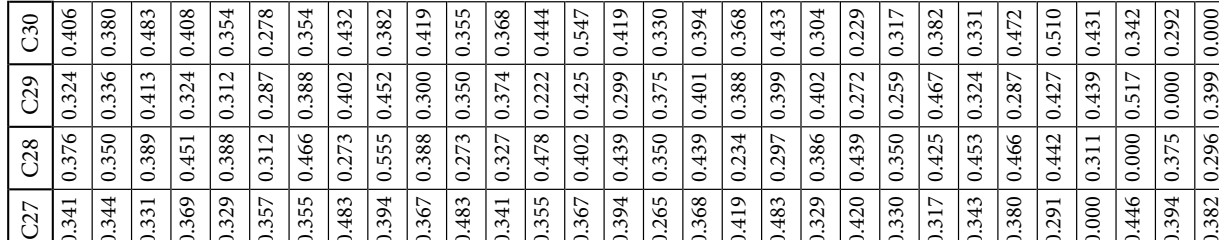

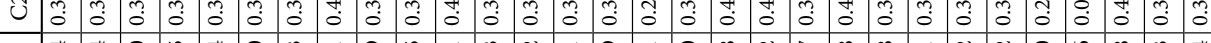

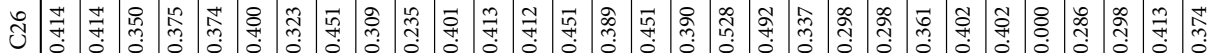

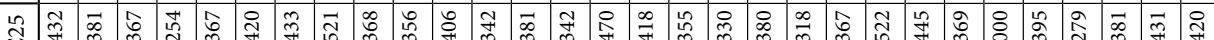

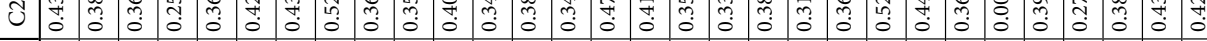

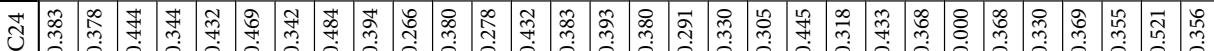

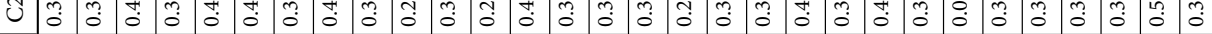
య

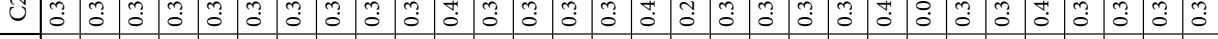
ส

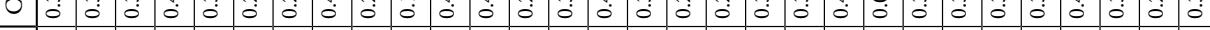

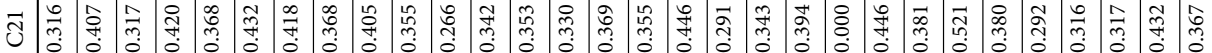

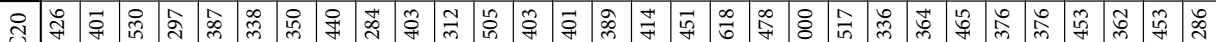

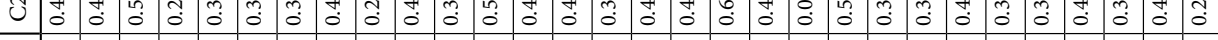

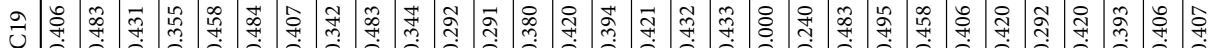

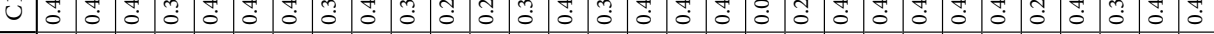

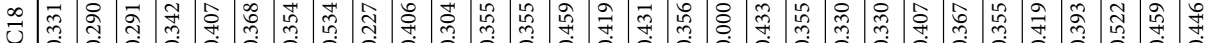

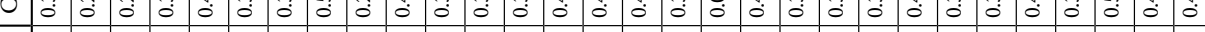

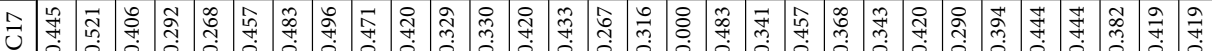

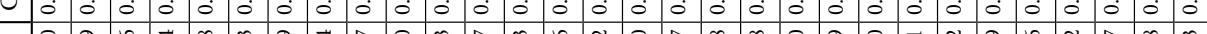

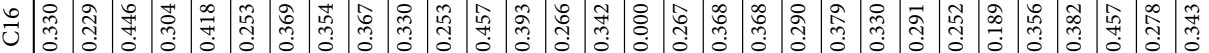

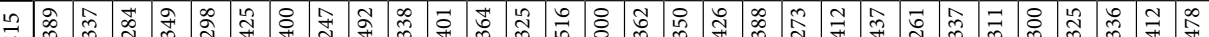

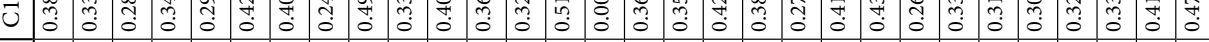

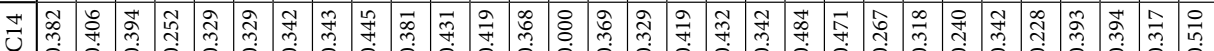

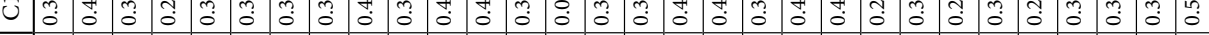

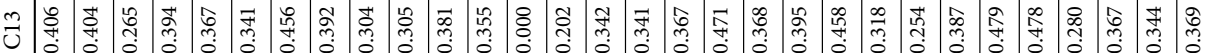

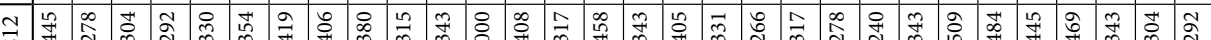

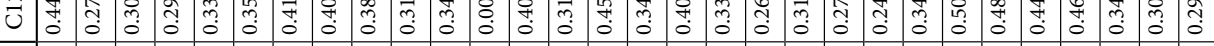

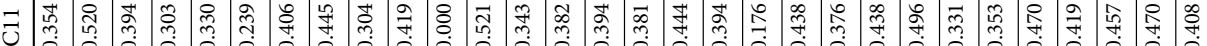
\begin{tabular}{c}
7 \\
\hdashline
\end{tabular}

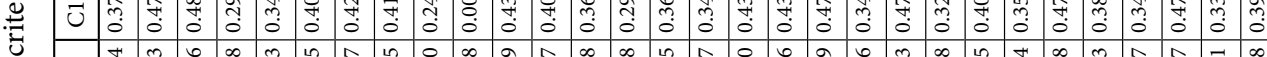

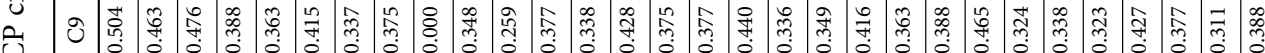

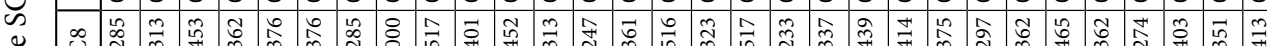
$\cong$

4

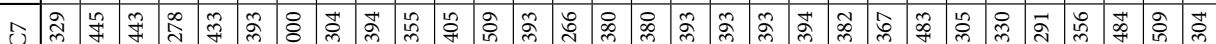

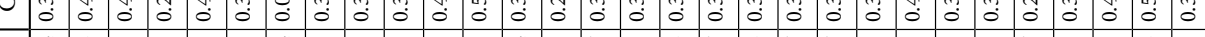

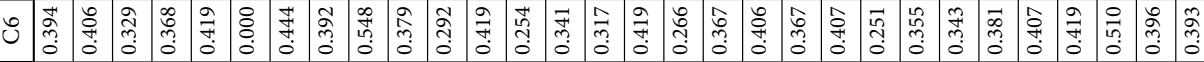

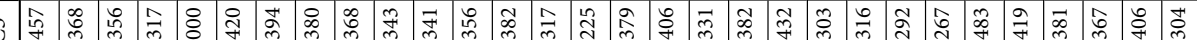

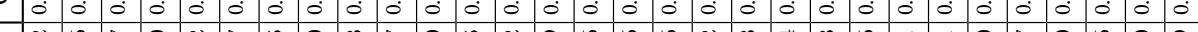

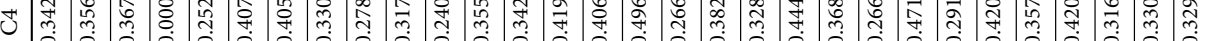

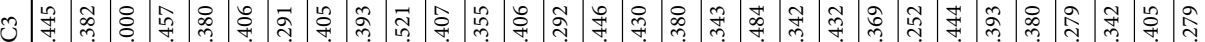

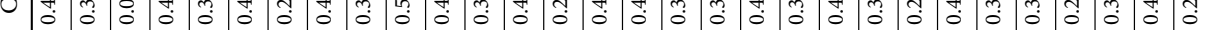
บ ป כ)

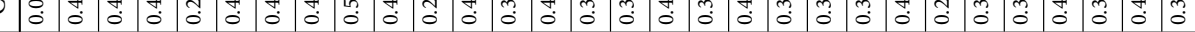

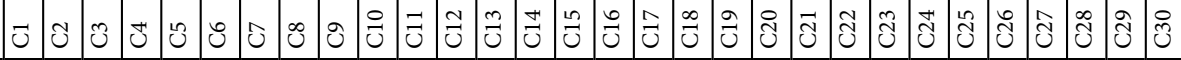




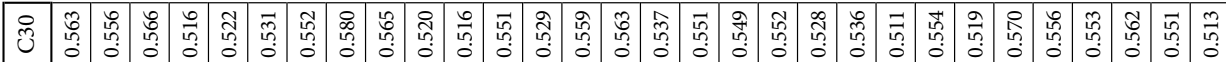

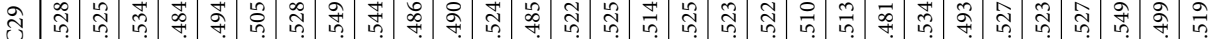
ปे hै

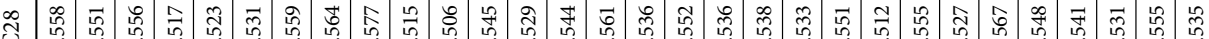

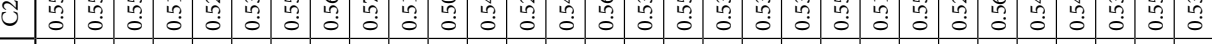

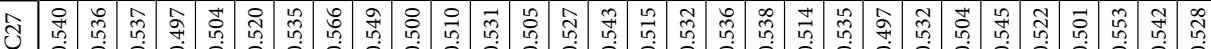
उ人)

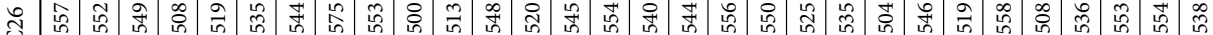

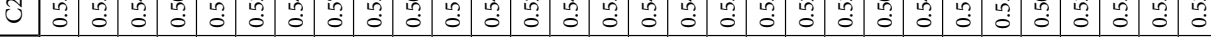

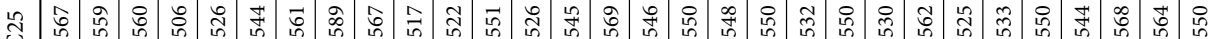
\begin{tabular}{lllllllllllllllllllllllllllllll} 
& 0 & 0 & 0 & 0 & 0 & 0 & 0 & 0 & 0 & 0 & 0 & 0 & 0 & 0 & 0 & 0 & 0 & 0 & 0 & 0 & 0 & 0 & 0 & 0 & 0 & 0 & 0 & 0 & 0 & 0 \\
\hline
\end{tabular}

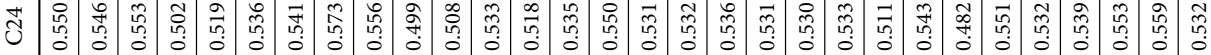

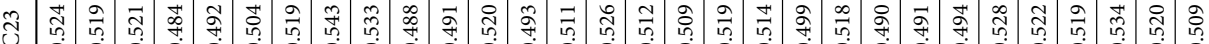

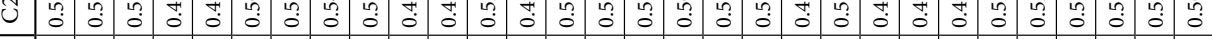

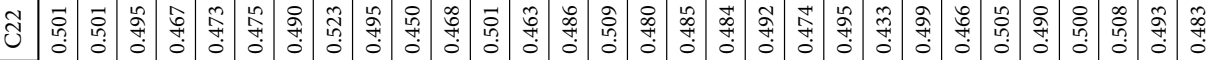

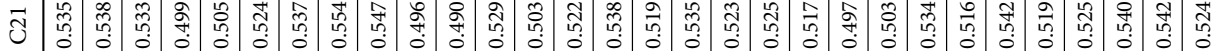
స

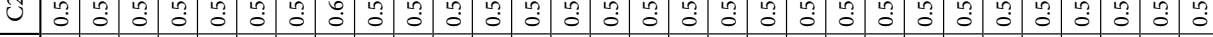

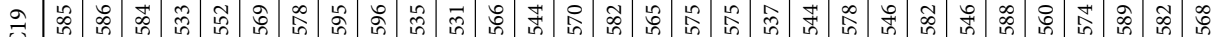

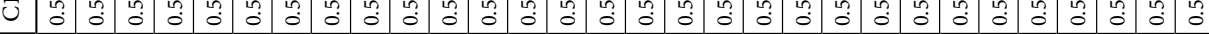

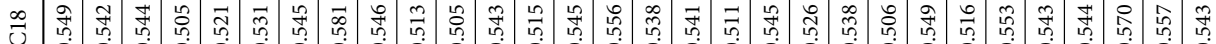

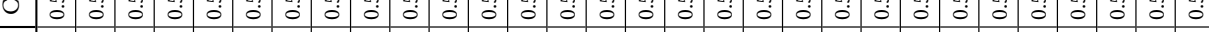

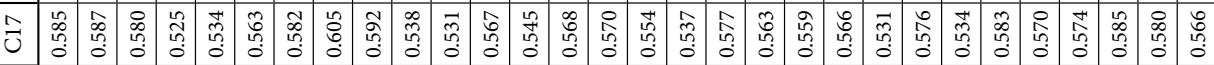

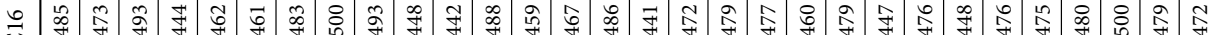

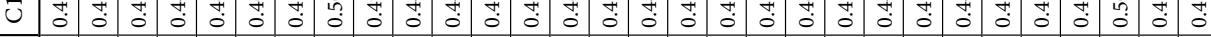

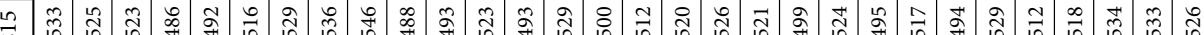

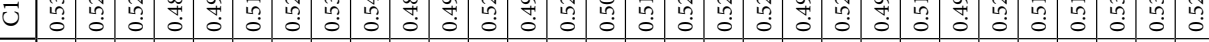
$\exists$ J

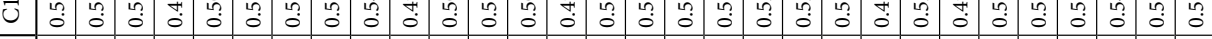

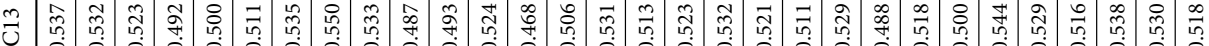

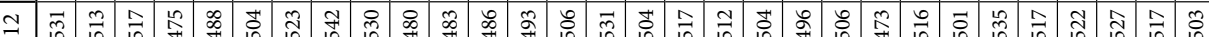

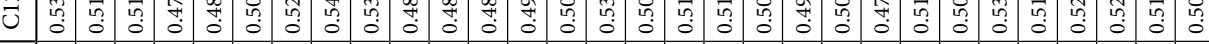

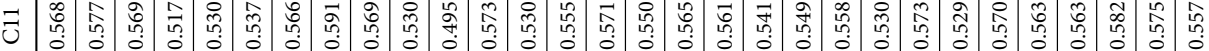

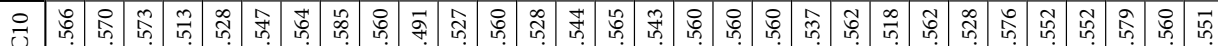

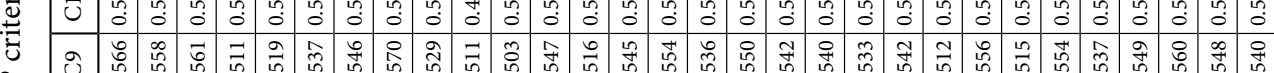

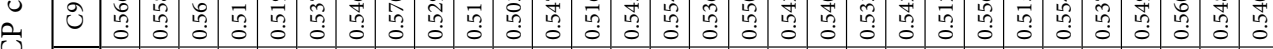

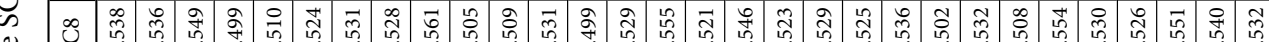

$\Xi$

पै

焉

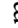

.

密

प্ّ

:

స్ㅠㅇㅠ.

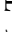
尝

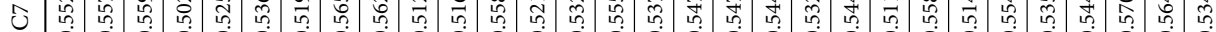
0 (

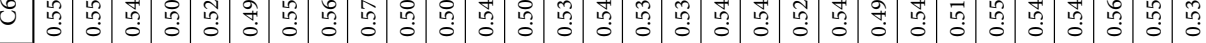

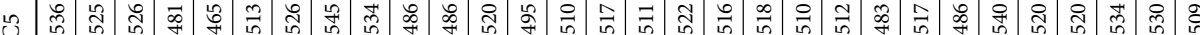

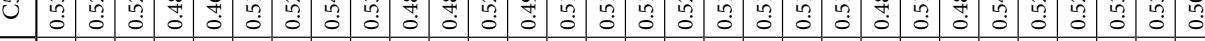

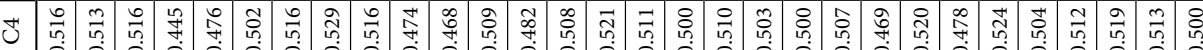

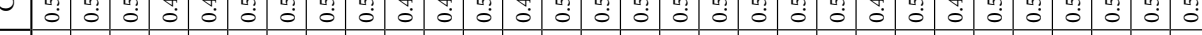

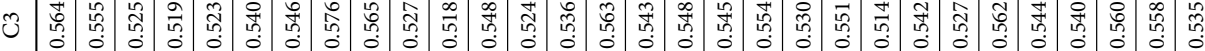

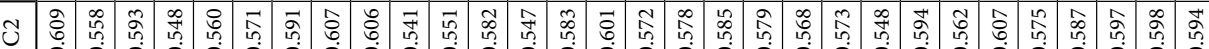

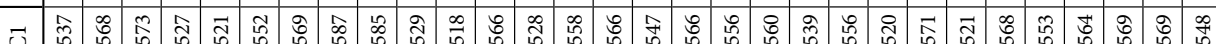

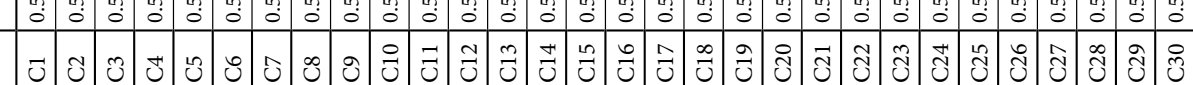


Table 7. Sum of influences given and received on the SCP criteria

\begin{tabular}{|c|c|c|c|c|}
\hline Criteria & $V^{d}$ & $V^{r}$ & $V^{d}+V^{r}$ & $V^{d}-V^{r}$ \\
\hline $\mathrm{C} 1$ & 16.465 & 16.339 & 32.803 & 0.126 \\
\hline C2 & 17.232 & 16.207 & 33.440 & 1.025 \\
\hline C3 & 16.154 & 16.270 & 32.425 & $(0.116)$ \\
\hline $\mathrm{C} 4$ & 14.947 & 14.910 & 29.857 & 0.037 \\
\hline C5 & 15.277 & 15.240 & 30.517 & 0.037 \\
\hline C6 & 15.950 & 15.674 & 31.624 & 0.276 \\
\hline C7 & 16.083 & 16.152 & 32.235 & $(0.068)$ \\
\hline $\mathrm{C} 8$ & 15.744 & 16.819 & 32.563 & $(1.075)$ \\
\hline C9 & 16.072 & 16.499 & 32.571 & $(0.427)$ \\
\hline $\mathrm{C} 10$ & 16.394 & 15.005 & 31.398 & 1.389 \\
\hline C11 & 16.518 & 15.010 & 31.529 & 1.508 \\
\hline $\mathrm{C} 12$ & 15.136 & 16.071 & 31.207 & $(0.936)$ \\
\hline $\mathrm{C} 13$ & 15.411 & 15.203 & 30.614 & 0.208 \\
\hline C14 & 15.552 & 15.870 & 31.422 & $(0.318)$ \\
\hline C15 & 15.355 & 16.309 & 31.664 & $(0.954)$ \\
\hline $\mathrm{C} 16$ & 14.038 & 15.728 & 29.767 & $(1.690)$ \\
\hline $\mathrm{C} 17$ & 16.797 & 16.009 & 32.806 & 0.788 \\
\hline $\mathrm{C} 18$ & 15.998 & 16.011 & 32.009 & $(0.014)$ \\
\hline C19 & 16.885 & 15.934 & 32.819 & 0.951 \\
\hline $\mathrm{C} 20$ & 17.117 & 15.546 & 32.663 & 1.571 \\
\hline $\mathrm{C} 21$ & 15.590 & 15.965 & 31.555 & $(0.376)$ \\
\hline $\mathrm{C} 22$ & 14.474 & 14.975 & 29.449 & $(0.501)$ \\
\hline $\mathrm{C} 23$ & 15.232 & 16.139 & 31.370 & $(0.907)$ \\
\hline $\mathrm{C} 24$ & 15.892 & 15.198 & 31.090 & 0.694 \\
\hline $\mathrm{C} 25$ & 16.285 & 16.399 & 32.684 & $(0.114)$ \\
\hline $\mathrm{C} 26$ & 16.025 & 15.903 & 31.928 & 0.121 \\
\hline $\mathrm{C} 27$ & 15.673 & 16.004 & 31.678 & $(0.331)$ \\
\hline $\mathrm{C} 28$ & 16.137 & 16.503 & 32.640 & $(0.365)$ \\
\hline C29 & 15.372 & 16.273 & 31.646 & $(0.901)$ \\
\hline C30 & 16.205 & 15.843 & 32.049 & 0.362 \\
\hline
\end{tabular}

Table 8. Sum of influences given and received on the aspects

\begin{tabular}{|c|c|c|c|c|}
\hline Aspects & $V^{d}$ & $V^{r}$ & $V^{d}+V^{r}$ & $V^{d}-V^{r}$ \\
\hline A1 & 2.414 & 3.730 & 6.145 & $(1.316)$ \\
\hline A2 & 4.559 & 3.852 & 8.412 & 0.707 \\
\hline A3 & 2.522 & 1.874 & 4.396 & 0.648 \\
\hline A4 & 4.040 & 4.265 & 8.305 & $(0.225)$ \\
\hline A5 & 4.465 & 2.946 & 7.411 & 1.520 \\
\hline A6 & 2.644 & 3.978 & 6.622 & $(1.334)$ \\
\hline
\end{tabular}




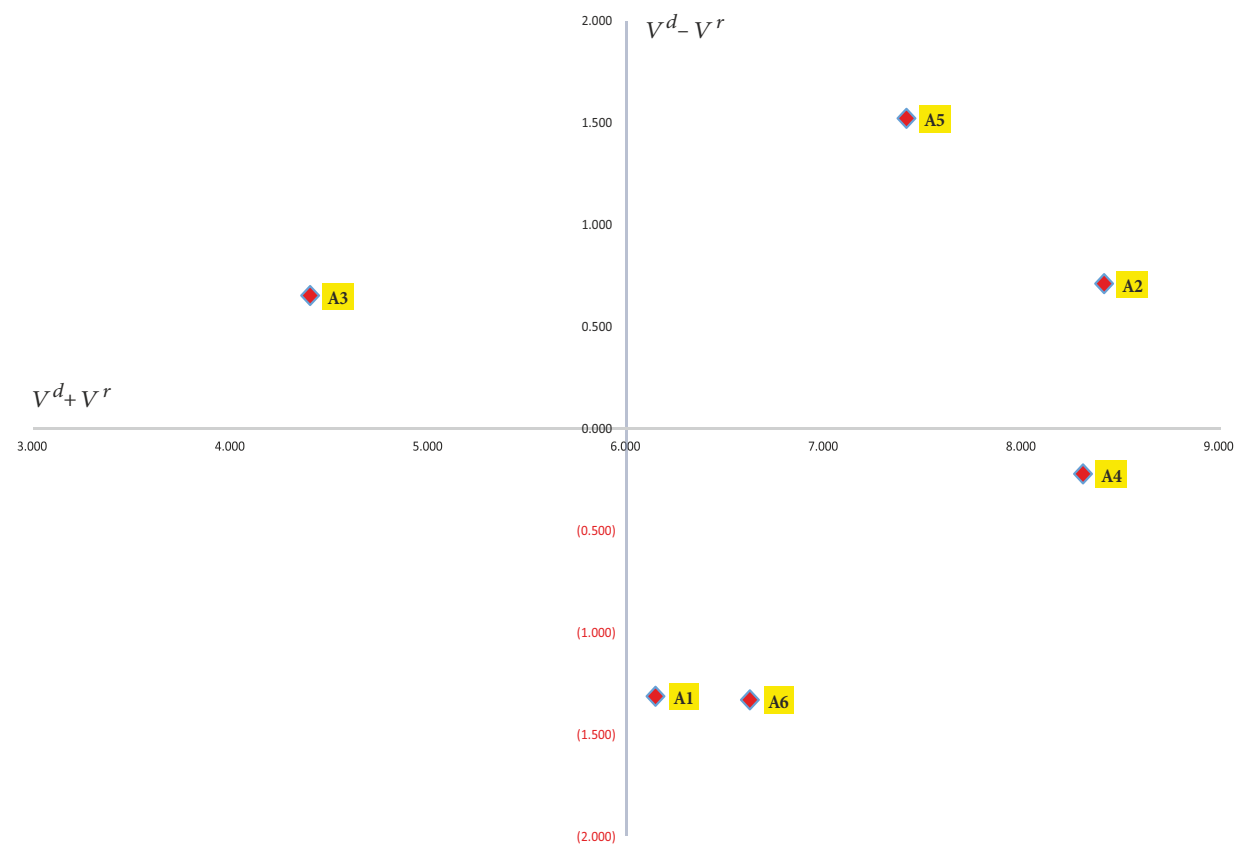

Figure 2. The cause and effect diagram of the aspects

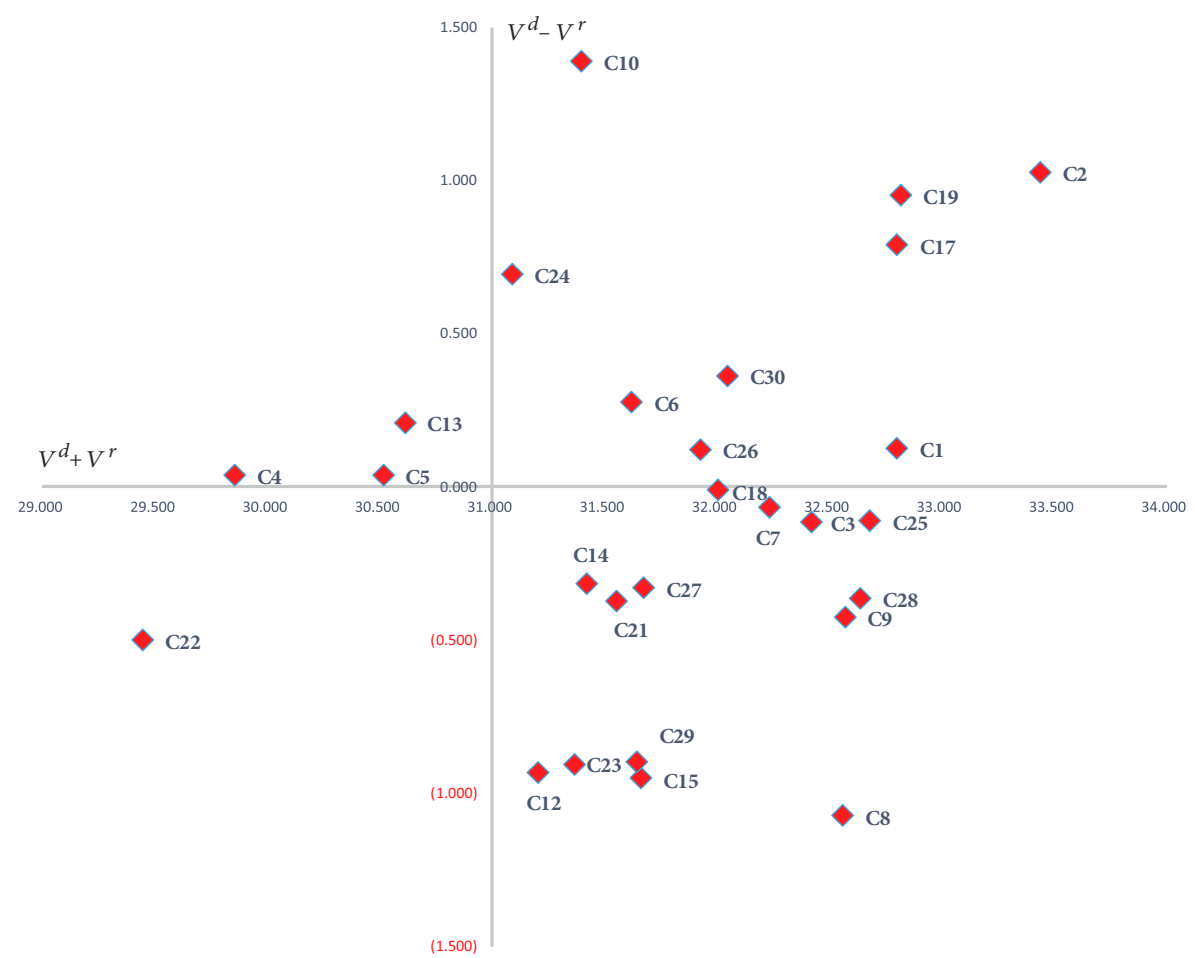

Figure 3. The cause and effect diagram of the SCP criteria 


\section{Discussion and implications}

\subsection{Theoretical implications}

Several theoretical implications can be concluded from the results of the study. First, the study adopts the eco-innovation theory to explore SCP in the rapidly changing environment through multidimensional evaluation, which can establish a theoretical framework between eco-innovation and SCP. Second, the results which showed that SCP could be achieved by applying the eco-innovation agree with previous studies that suggest eco-innovation is the driver of SCP in some specific environment and practices (Giacomo et al., 2014). Finally, the study overcomes the drawback of DEMATEL by adopting the fuzzy set theory, which can reduce the uncertainty caused by experts' evaluation. Therefore, the empirical results are more accurate and reliable.

Furthermore, two important aspects should be discussed. Environment (A2) aspect, which stresses that the global environment is closely related to production and consumption trends, is considered to have the highest impact on SCP. Therefore, firms must consider the environment when making strategies towards SCP. However, development without sacrificing the environment has been emphasized and appealed for many years, but firms are profit-oriented and tend to ignore environmental issues. The results indicated that life cycle assessment, as well as eco-labels and environmental certification, are practical and rational ways to pursue SCP for firms without damaging the environment. Life cycle assessment can avoid and reduce environmental burden ( Wu \& Ma, 2018), and eco-labels and environmental certification can verify the overall environmental performance of a product or service within a particular product category (Cai, Xie, \& Aguilar, 2017). In short, this aspect can lead firms to comply with regulations and policies and gain customer recognition.

Sustainable consumption (A5) is important to meet basic needs, improve life quality, and minimize the consumption of natural resources (Lim, 2017). It has become one of the policy factors that are increasingly important in strategies of national sustainable development (Seyfang, 2006). However, a clear understanding of the key drivers of sustainable consumption is a significant challenge for many firms. The results confirmed that although this aspect is the driving factor of SCP, the actions taken by firms are insufficient. Therefore, the study suggested that providing eco-demand for the customer, enhanced communication, and reuse and recycling can be adopted to improve the situation. It can be concluded that the comprehensive integration of sustainable consumption is not only a business strategy but also an effective management and market-based demand (Jones et al., 2014).

\subsection{Managerial implications}

As a valuable tool for sustainability assessment, life cycle assessment (C6) provides quantitative and overall information on the consumption of resources and potential environmental impacts. However, an increasing number of firms have realized that life cycle assessment can bring many benefits, but the practice is still insufficient due to management philosophy and limited resources. Accordingly, life cycle assessment is usually made up of four stages (Sharma, Saxena, Sethi, \& Shree, 2011). First, firms should define the analysis aim, system 
boundary, and the functional unit and assumption. Second, establishing an analysis of inventory is required for when data about materials and energy consumption as well as wastes and emissions are collected, identified and quantified. Third, assessing the environmental impact of the previous stage by classifying, characterizing, normalizing, evaluating, and setting impact categories is necessary. Finally, based on the information gathered from the second and third stages, firms should analyze the inventory and environmental impact assessment while assisting in the decision-making.

Eco-labels and environmental certification (C10) can help increase firms' competitiveness and brand awareness, acquire customers' recognition, and support product differentiation. Currently, adopting this practice means firms may change the production structure, increase investments and utilize complex technologies. In the long term, it can generate positive impacts. Therefore, if firms want to make greener products or services, they should adjust traditional production mode, increase investments in adopting clean technologies and environmentally friendly packaging, and compile independently verified environmental information into a report format. Moreover, firms can also make their products or services evaluated or validated by authorities or governments, such as ISO certification, to gain client trust and market recognition.

Improving eco-efficiency (C24) can assist firms towards qualitative growth, increasing productivity, profits and value, rather than converting a larger quantity of materials into energy and waste. The adoption of this practice can also save time, reduce pollution, and produce higher-quality products. Moreover, firms can reduce the consumption of resources for goods and services and toxic substance dispersion, improve materials recyclability, and maximize the utilization of renewable resources to improve sustainable consumption performance. In addition, the increase in product durability, value aggregation to products and services, as well as the enhancement of employees' skills are feasible to improve eco-efficiency for firms.

Apart from the three criteria discussed above, other criteria located in the first quadrant are thought to be the driving factors that allow firms to explore SCP. Investments in equipment and technology reformation (C2) and Firm's R\&D expenditure (C1) are under economic (A1) aspect. In corporate governance (A4) aspect, firms can adopt the practices of cooperation with external partners (C19) and product orientation (C17). The number of patent applications (C30) and pollution control and prevention (C26) are under sustainable production (A6).

\section{Conclusions}

Pursuing a sustainable pattern of both consumption and production has become a vital strategy for many construction firms. Eco-innovation can be a noteworthy measure for firms to accomplish their aims and improve sustainable performance. However, the issues defining SCP and the role of eco-innovation remain unclear. Therefore, thirty criteria of eco-innovation as evaluating factors were successfully proposed in six aspects based on SCP through literature review and expert discussion. The evaluation process was conducted using the fuzzy DEMATEL method and based on the expert committee's response. Meanwhile, the fuzzy set theory was adopted to overcome uncertain information generated by experts' as- 
sessments and transform qualitative information into quantitative assessments. Then, the DEMATEL method was used to investigate the causal inter-relationship among different aspects and criteria, and generate more valuable information that can provide a precise guide for practical applications.

Several contributions are provided in this work. This study reinforces the understanding of SCP and theoretically establishes its link with eco-innovation. In addition, convincing explanations of SCP development can be seen in the framework proposed in this study. The study provides a managerial contribution to the construction firms in China by assisting them to improve the patterns of consumption and production through the proposed criteria of eco-innovation to develop sustainable practices. With regard to the methodological contribution, the proposed FDEMATEL method can overcome the uncertain information generated by experts' judgments and create clear cause and effect diagrams, which can help decision-makers reduce assessment complexity and simplify decision-making processes.

The results also indicated that launching eco-innovation helps the construction firms achieve SCP. Environment and sustainable consumption are significant decisive aspects of SCP. Therefore, the majority of resources should be shifted by construction firms to enhance the performance toward environmentally friendly production activities and sustainable consumption patterns. The study suggests that the life cycle assessment, eco-labels and environmental certification as well as improving eco-efficiency are the preferred measures when the construction firms implement SCP strategy. In addition, several practices under the other aspects are equally the driving factors for SCP, such as investments in equipment and technology reformation and cooperation with external partners. Thus, if firms have suitable resources and conditions, these sustainable practices can also be taken into account.

Furthermore, firms should clearly understand the four processes of life cycle assessment: set aims and boundaries, inventory analysis, impact assessment, and making interpretations for giving conclusions and advice. Eco-labels and environmental certification are the practice that suggests firms using advanced technologies, adopting green packaging as well as providing environmental information report. Firms should acquire eco-certification, such as ISO certification. In addition, it is recommended that improving eco-efficiency should firstly reduce unnecessary resources consumption and toxic substance dispersion and then improve reuse and recycling performance. Enhancing product durability, aggregating product and service value, and improving employee skills also help to improve firms' eco-efficiency. In short, these eco-innovation practices provide insights for construction firms to improve effectiveness, reduce pollution and waste generation, and minimize resource consumption, thereby successfully implementing SCP strategy.

However, the proposed six aspects of SCP and thirty criteria of the eco-innovation utilized in the analysis may not be exhaustive. Therefore, the evaluation process could include more aspects and criteria for future research. This study researched the construction industry only in China. Therefore, the generalizability of the findings may be limited. Future research will expand the evaluation process to analyze other sectors or more case studies in other countries to make a comparative analysis. Furthermore, the experts involved in the study were specialized in the construction industry. Thus, other experts from various fields can form an expert group to bring different values and advice for future research. 


\section{Acknowledgements}

The authors would like to thank the anonymous referees for their valuable comments and suggestions. The funding of this study was supported by the National Social Science Funding Program (15BGL023).

\section{Funding}

This work was supported by the $<$ National Social Science Funding Program $>$ under Grant [15BGL023].

\section{Author contributions}

Author Contributions: Li Ma contributed to research design, organization of survey, data collection and analysis, and discussion; Liang Wang contributed to literature review, factor identification, and data analysis; Mirosław J. Skibniewski contributed to research design, linguistic check and modification; Waldemar Gajda contributed to linguistic check and modification.

\section{Disclosure statement}

The authors declare no conflict of interest.

\section{References}

Akbiyikli, R., Eaton, D., \& Dikmen, S. U. (2012). Achieving sustainable construction within private finance initiative (PFI) road projects in the UK. Technological and Economic Development of Economy, 18(2), 207-229. https://doi.org/10.3846/20294913.2012.677586

Akenji, L., \& Bengtsson, M. (2014). Making sustainable consumption and production the core of sustainable development goals. Sustainability, 6(2), 513-529. https://doi.org/10.3390/su6020513

Aras, G., \& Crowther, D. (2008). Governance and sustainability: An investigation into the relationship between corporate governance and corporate sustainability. Social Science Electronic Publishing, 46(3), 433-448. https://doi.org/10.1108/00251740810863870

Azapagic, A., Stamford, L., Youds, L., \& Barteczko-Hibbert, C. (2016). Towards sustainable production and consumption: A novel decision-support framework integrating economic, environmental and social sustainability (DESIRES). Computers \& Chemical Engineering, 91, 93-103. https://doi.org/10.1016/j.compchemeng.2016.03.017

Bai, C., Shah, P., Zhu, Q., \& Sarkis, J. (2018). Green product deletion decisions: An integrated sustainable production and consumption approach. Industrial Management \& Data Systems, 118(2), 349389. https://doi.org/10.1108/IMDS-05-2017-0175

Berg, A. (2011). Not roadmaps but toolboxes: Analysing pioneering national programmes for sustainable consumption and production. Journal of Consumer Policy, 34(1), 9-23. https://doi.org/10.1007/s10603-010-9129-2

Blok, V., Long, T. B., Gaziulusoy, A. I., Ciliz, N., Lozano, R., Huisingh, D., Csutora, M., \& Boks, C. (2015). From best practices to bridges for a more sustainable future: Advances and challenges in the 
transition to global sustainable production and consumption: Introduction to the ERSCP stream of the Special volume. Journal of Cleaner Production, 108, 19-30.

https://doi.org/10.1016/j.jclepro.2015.04.119

Bönte, W., \& Dienes, C. (2013). Environmental innovations and strategies for the development of new production technologies: empirical evidence from Europe. Business Strategy and the Environment, 22(8), 501-516. https://doi.org/10.1002/bse.1753

Bossle, M. B., Dutra De Barcellos, M., Vieira, L. M., \& Sauvée, L. (2016). The drivers for adoption of eco-innovation. Journal of Cleaner Production, 113, 861-872. https://doi.org/10.1016/j.jclepro.2015.11.033

Cai, W., \& Li, G. (2018). The drivers of eco-innovation and its impact on performance: Evidence from China. Journal of Cleaner Production, 176, 110-118. https://doi.org/10.1016/j.jclepro.2017.12.109

Cai, Z., Xie, Y., \& Aguilar, F. X. (2017). Eco-label credibility and retailer effects on green product purchasing intentions. Forest Policy \& Economics, 80, 200-208. https://doi.org/10.1016/j.forpol.2017.04.001

Carrillo-Hermosilla, J., Del González, P. R., \& Könnölä, T. (2009). What is eco-innovation? In EcoInnovation (pp. 6-27). London: Palgrave Macmillan.

Cohen, B., \& Winn, M. I. (2007). Market imperfections, opportunity and sustainable entrepreneurship. Journal of Business Venturing, 22(1), 29-49. https://doi.org/10.1016/j.jbusvent.2004.12.001

Cui, L. (2017). Fuzzy approach to eco-innovation for enhancing business functions: A case study in China. Industrial Management \& Data Systems, 117(5), 967-987. https://doi.org/10.1108/IMDS-02-2017-0041

de Jesus, A., \& Mendonça, S. (2018). Lost in transition? Drivers and barriers in the eco-innovation road to the circular economy. Ecological Economics, 145, 75-89.

https://doi.org/10.1016/j.ecolecon.2017.08.001

Del Río, P., Carrillo-Hermosilla, J., Könnölä, T., \& Bleda, M. (2016). Resources, capabilities and competences for eco-innovation. Technological and Economic Development of Economy, 22(2), 274-292. https://doi.org/10.3846/20294913.2015.1070301

Dočekalová, M. P., Doubravský, K., Dohnal, M., \& Kocmanová, A. (2017). Evaluations of corporate sustainability indicators based on fuzzy similarity graphs. Ecological Indicators, 78, 108-114. https://doi.org/10.1016/j.ecolind.2017.02.038

Dong, Y., Wang, X., Jin, J., Qiao, Y., \& Shi, L. (2014). Effects of eco-innovation typology on its performance: Empirical evidence from Chinese enterprises. Journal of Engineering \& Technology Management, 34, 78-98. https://doi.org/10.1016/j.jengtecman.2013.11.001

Dubey, R., Gunasekaran, A., Childe, S. J., Papadopoulos, T., Wamba, S. F., \& Song, M. (2016). Towards a theory of sustainable consumption and production: Constructs and measurement. Resources Conservation \& Recycling, 106, 78-89. https://doi.org/10.1016/j.resconrec.2015.11.008

Faucheux, S., \& Nicolaï, I. (2011). IT for green and green IT: A proposed typology of eco-innovation. Ecological Economics, 70(11), 2020-2027. https://doi.org/10.1016/j.ecolecon.2011.05.019

Gan, X., Zuo, J., Ye, K., Skitmore, M., \& Xiong, B. (2015). Why sustainable construction? Why not? An owner's perspective. Habitat International, 47, 61-68. https://doi.org/10.1016/j.habitatint.2015.01.005

García-Pozo, A., Sánchez-Ollero, J. L., \& Marchante-Lara, M. (2015). Eco-innovation and management: an empirical analysis of environmental good practices and labour productivity in the Spanish hotel industry. Innovation: Organization \& Management, 17(1), 58-68. https://doi.org/10.1080/14479338.2015.1011057

Geels, F. W., McMeekin, A., Mylan, J., \& Southerton, D. (2015). A critical appraisal of sustainable consumption and production research: The reformist, revolutionary and reconfiguration positions. Global Environmental Change, 34, 1-12. https://doi.org/10.1016/j.gloenvcha.2015.04.013 
Giacomo, M. R. D., Loprieno, A., Tarantini, M., Preka, R., Litido, M., Furphy, A., Calvo, V., LlorachMassana, P., Gasol, C., Rieradevall, J., Farreny, R., \& Gabarrell, X. (2014). Eco-innovative practices for sustainable consumption and production: What are the possiblebenefits for companies? Administrative Sciences, 4(3), 242-275. https://doi.org/10.3390/admsci4030242

Govindan, K. (2018). Sustainable consumption and production in the food supply chain: A conceptual framework. International Journal of Production Economics, 195, 419-431.

https://doi.org/10.1016/j.ijpe.2017.03.003

Hahn, T., \& Figge, F. (2011). Beyond the bounded instrumentality in current corporate sustainability research: Toward an inclusive notion of profitability. Journal of Business Ethics, 104(3), 325-345. https://doi.org/10.1007/s10551-011-0911-0

Heravi, G., \& Charkhakan, M. H. (2014). Predicting and tracing change-formation scenarios in construction projects using the DEMATEL technique. Journal of Management in Engineering, 30, 4014028. https://doi.org/10.1061/(ASCE)ME.1943-5479.0000229

Hitchens, D. M. W. N. (1999). The implications for competitiveness of environmental regulations for peripheral regions in the E.U. Omega, 27(1), 101-114. https://doi.org/10.1016/S0305-0483(98)00027-9

Hojnik, J., \& Ruzzier, M. (2016). What drives eco-innovation? A review of an emerging literature. Environmental Innovation and Societal Transitions, 19, 31-41. https://doi.org/10.1016/j.eist.2015.09.006

Hong, Y. J., Shin, D., \& Kim, J. H. (2016). High/low reputation companies' dialogic communication activities and semantic networks on Facebook: A comparative study. Technological Forecasting and Social Change, 110, 78-92. https://doi.org/10.1016/j.techfore.2016.05.003

Horbach, J. (2008). Determinants of environmental innovation - new evidence from German panel data sources. Research Policy, 37(1), 163-173. https://doi.org/10.1016/j.respol.2007.08.006

Horbach, J., Rammer, C., \& Rennings, K. (2012). Determinants of eco-innovations by type of environmental impact - The role of regulatory push/pull, technology push and market pull. Ecological Economics, 78, 112-122. https://doi.org/10.1016/j.ecolecon.2012.04.005

Jackson, T. (2006). Readings in sustainable consumption. In The Earthscan reader in sustainable consumption (pp. 1-27). London: Earthscan.

Jang, W., Lee, S. K., \& Han, S. H. (2018). Sustainable performance index for assessing the green technologies in urban infrastructure projects. Journal of Management in Engineering, 34, 4017056. https://doi.org/10.1061/(ASCE)ME.1943-5479.0000582

Jones, E., Stanton, N. A., \& Harrison, D. (2001). Applying structured methods to eco-innovation. An evaluation of the product ideas tree diagram. Design Studies, 22(6), 519-542. https://doi.org/10.1016/S0142-694X(01)00007-2

Jones, P., Hillier, D., Comfort, D., Jones, P., Hillier, D., \& Comfort, D. (2014). Sustainable consumption and the UK's leading retailers. Social Responsibility Journal, 10(4), 702-715. https://doi.org/10.1108/SRJ-04-2013-0046

Kemp, R., \& Pearson, P. (2007). Final report MEI project about measuring eco-innovation (pp. 121-124). UM Merit, Maastricht.

Kesidou, E., \& Demirel, P. (2012). On the drivers of eco-innovations: Empirical evidence from the UK. Research Policy, 41(5), 862-870. https://doi.org/10.1016/j.respol.2012.01.005

Kiefer, C. P., Carrillo-Hermosilla, J., Del Río, P., \& Callealta Barroso, F. J. (2017). Diversity of ecoinnovations: A quantitative approach. Journal of Cleaner Production, 166, 1494-1506. https://doi.org/10.1016/j.jclepro.2017.07.241

Kumar, A., \& Dixit, G. (2018). Evaluating critical barriers to implementation of WEEE management using DEMATEL approach. Resources Conservation \& Recycling, 131, 101-121.

https://doi.org/10.1016/j.resconrec.2017.12.024 
Keršulienè, V., \& Turskis, Z. (2011). Integrated fuzzy multiple criteria decision making model for architect selection. Technological and Economic Development of Economy, 17(4), 645-666. https://doi.org/10.3846/20294913.2011.635718

Latif, K. F., \& Williams, N. (2017). Team effectiveness in non-governmental organizations (NGOs) projects. Evaluation and Program Planning, 64, 20-32. https://doi.org/10.1016/j.evalprogplan.2017.05.004

Lim, W. M. (2017). Inside the sustainable consumption theoretical toolbox: Critical concepts for sustainability, consumption, and marketing. Journal of Business Research, 78, 69-80. https://doi.org/10.1016/j.jbusres.2017.05.001

Lin, J. Y. (2017). Balancing industry collaboration and academic innovation: The contingent role of collaboration-specific attributes. Technological Forecasting and Social Change, 123, 216-228. https://doi.org/10.1016/j.techfore.2016.03.016

Lin, Y., Tseng, M. L., Chen, C. C., \& Chiu, A. S. F. (2011). Positioning strategic competitiveness of green business innovation capabilities using hybrid method. Expert Systems with Applications, 38(3), 1839-1849. https://doi.org/10.1016/j.eswa.2010.07.113

Liobikienè, G., \& Dagiliūte, R. (2016). The relationship between economic and carbon footprint changes in EU: The achievements of the EU sustainable consumption and production policy implementation. Environmental Science \& Policy, 61, 204-211. https://doi.org/10.1016/j.envsci.2016.04.017

Liu, C., Valentine, G., Vanderbeck, R. M., McQuaid, K., \& Diprose, K. (2018). Placing 'sustainability' in context: narratives of sustainable consumption in Nanjing, China. Social \& Cultural Geography, 1-18. https://doi.org/10.1080/14649365.2018.1454978

Luo, Z., Dubey, R., Gunasekaran, A., Childe, S. J., Papadopoulos, T., Hazen, B., \& Roubaud, D. (2017). Sustainable production framework for cement manufacturing firms: A behavioural perspective. Renewable and Sustainable Energy Reviews, 78, 495-502. https://doi.org/10.1016/j.rser.2017.04.069

Luthra, S., Govindan, K., \& Mangla, S. K. (2017). Structural model for sustainable consumption and production adoption - A grey-DEMATEL based approach. Resources Conservation \& Recycling, 125, 198-207. https://doi.org/10.1016/j.resconrec.2017.02.018

Machiba, T. (2010). Eco-innovation for enabling resource efficiency and green growth: Development of an analytical framework and preliminary analysis of industry and policy practices. International Economics and Economic Policy, 7(2-3), 357-370. https://doi.org/10.1007/s10368-010-0171-y

Martin, L., McNeill, T., \& Warren-Smith, I. (2013). Exploring business growth and eco innovation in rural small firms. International Journal of Entrepreneurial Behavior \& Research, 19(6), 592-610. https://doi.org/10.1108/IJEBR-10-2012-0118

Michaelis, L. (2003). The role of business in sustainable consumption. Journal of Cleaner Production, 11(8), 915-921. https://doi.org/10.1016/S0959-6526(02)00160-9

Ociepa-Kubicka, A., \& Pachura, P. (2017). Eco-innovations in the functioning of companies. Environmental Research, 156, 284-290. https://doi.org/10.1016/j.envres.2017.02.027

Oslo Symposium. (1994). Oslo rountable on sustainable production and consumption. Retrieved from http://www.iisd.ca/consume/oslo004.html

Pallaro, E., Subramanian, N., Abdulrahman, M. D., \& Liu, C. (2015). Sustainable production and consumption in the automotive sector: Integrated review framework and research directions. Sustainable Production and Consumption, 4(2), 47-61. https://doi.org/10.1016/j.spc.2015.07.002

Pourahmad, A., Hosseini, A., Banaitis, A., Nasiri, H., Banaitienė, N., \& Tzeng, G. H. (2015). Combination of fuzzy-AHP and DEMATEL-ANP with GIS in a new hybrid MCDM model used for the selection of the best space for leisure in a blighted urban site. Technological and Economic Development of Economy, 21(5), 773-796. https://doi.org/10.3846/20294913.2015.1056279

Roddis, P. (2018). Eco-innovation to reduce biodiversity impacts of wind energy: Key examples and drivers in the UK. Environ. Environmental Innovation and Societal Transitions, 28, 46-56.

https://doi.org/10.1016/j.eist.2018.03.003 
Sanni, M. (2018). Drivers of eco-innovation in the manufacturing sector of Nigeria. Technological Forecasting and Social Change, 131, 303-314. https://doi.org/10.1016/j.techfore.2017.11.007

Santos, D. F. L., Basso, L. F. C., Kimura, H., \& Sobreiro, V. A. (2015). Eco-innovation in the Brazilian sugar-ethanol industry: a case study. Brazilian Journal of Science and Technology, 2(1), 1. https://doi.org/10.1186/s40552-014-0006-4

Scarpellini, S., Valero-Gil, J., \& Portillo-Tarragona, P. (2016). The "economic-finance interface" for ecoinnovation projects. International Journal of Project Management, 34(6), 1012-1025. https://doi.org/10.1016/j.ijproman.2016.04.005

Schinkel, M. P., \& Spiegel, Y. (2017). Can collusion promote sustainable consumption and production? International Journal of Industrial Organization, 53, 371-398. https://doi.org/10.1016/j.ijindorg.2016.04.012

Segarra-Oña, M. del V., Peiró-Signes, A., \& Cervelló-Royo, R. (2015). A framework to move forward on the path to eco-innovation in the construction industry: Implications to improve firms' sustainable orientation. Science \& Engineering Ethics, 21(6), 1469-1484. https://doi.org/10.1007/s11948-014-9620-2

Seyfang, G. (2004). Consuming values and contested cultures: a critical analysis of the UK strategy for sustainable consumption and production. Review of Social Economy, 62(3), 323-338. https://doi.org/10.1080/0034676042000253936

Seyfang, G. (2006). Ecological citizenship and sustainable consumption: Examining local organic food networks. Journal of Rural Studies, 22(4), 383-395. https://doi.org/10.1016/j.jrurstud.2006.01.003

Sharma, A., Saxena, A., Sethi, M., \& Shree, V. (2011). Life cycle assessment of buildings: a review. Renewable and Sustainable Energy Reviews, 15(1), 871-875. https://doi.org/10.1016/j.rser.2010.09.008

Shi, J., Li, Q., Li, H., Li, S., Zhang, J., \& Shi, Y. (2017). Eco-design for recycled products: Rejuvenating mullite from coal fly ash. Resources, Conservation and Recycling, 124, 67-73. https://doi.org/10.1016/j.resconrec.2017.04.005

Stevens, C. (2010). Linking sustainable consumption and production: The government role. Natural Resources Forum, 34(1), 16-23. https://doi.org/10.1111/j.1477-8947.2010.01273.x

Thongplew, N., Spaargaren, G., \& van Koppen, C. S. A. K. (2017). Companies in search of the green consumer: Sustainable consumption and production strategies of companies and intermediary organizations in Thailand. NJAS-Wageningen Journal of Life Sciences, 83, 12-21. https://doi.org/10.1016/j.njas.2017.10.004

Triguero, A., Moreno-Mondéjar, L., \& Davia, M. A. (2013). Drivers of different types of eco-innovation in European SMEs. Ecological Economics, 92, 25-33. https://doi.org/10.1016/j.ecolecon.2013.04.009

Tseng, M. L., Chiu, A. S. F., \& Liang, D. (2018). Sustainable consumption and production in business decision-making models. Resources, Conservation and Recycling, 128, 118-121. https://doi.org/10.1016/j.resconrec.2017.02.014

Tseng, M. L., Lim, M. K., Wong, W. P., Chen, Y. C., \& Zhan, Y. (2018). A framework for evaluating the performance of sustainable service supply chain management under uncertainty. International Journal of Production Economics, 195, 359-372. https://doi.org/10.1016/j.ijpe.2016.09.002

Tseng, M.-L., \& Tan, K. H. (2016). Sustainable consumption and production in emerging markets. International Journal of Production Economics, 181, 257-261. https://doi.org/10.1016/j.ijpe.2016.09.016

Wang, X., Chan, H. K., Lee, C. K. M., \& Li, D. (2015). A hierarchical model for eco-design of consumer electronic products. Technological and Economic Development of Economy, 21(1), 48-64. https://doi.org/10.3846/20294913.2013.876685

Wang, L., Ma, L., Wu, K. J., Chiu, A. S. F., \& Nathaphan, S. (2018). Applying fuzzy interpretive structural modeling to evaluate responsible consumption and production under uncertainty. Industrial Management \& Data Systems, 118(2), 432-462. https://doi.org/10.1108/IMDS-03-2017-0109 
Wang, R., Wang, F., Xu, L., \& Yuan, C. (2017). R\&D expenditures, ultimate ownership and future performance: Evidence from China. Journal of Business Research, 71(1), 47-54. https://doi.org/10.1016/j.jbusres.2016.10.018

Wong, W. P., Soh, K. L., \& Chong, C. Le (2016). Differentiated service consumption and low cost production: Striking a balance for a sustainable competitive advantage in Malaysia. Journal of Production Economics, 181, 450-459. https://doi.org/10.1016/j.ijpe.2015.09.029

Wu, K. J., Liao, C. J., Chen, C. C., Lin, Y., \& Tsai, C. F. M. (2016). Exploring eco-innovation in dynamic organizational capability under incomplete information in the Taiwanese lighting industry. International Journal of Production Economics, 181, 419-440. https://doi.org/10.1016/j.ijpe.2015.10.007

Wu, K. J., Liao, C. J., Tseng, M. L., \& Chiu, A. S. F. (2015). Exploring decisive factors in green supply chain practices under uncertainty. International Journal of Production Economics, 159, 147-157. https://doi.org/10.1016/j.ijpe.2014.09.030

Wu, K. J., Tseng, M. L., Chiu, A. S. F., \& Lim, M. K. (2017). Achieving competitive advantage through supply chain agility under uncertainty: A novel multi-criteria decision-making structure. International Journal of Production Economics, 190, 96-107. https://doi.org/10.1016/j.ijpe.2016.08.027

Wu, Y., \& Ma, H. (2018). Analysis of strategic environmental assessment in Taiwan energy policy and potential for integration with life cycle assessment. Environmental Impact Assessment Review, 71, 1-11. https://doi.org/10.1016/j.eiar.2018.03.005

Yang, F., \& Yang, M. (2015). Analysis on China's eco-innovations: Regulation context, intertemporal change and regional differences. European Journal of Operational Research, 247(3), 1003-1012. https://doi.org/10.1016/j.ejor.2015.07.029

Yiftachel, O., \& Hedgcock, D. (1993). Urban social sustainability. The planning of an Australian city. Cities, 10(2), 139-157. https://doi.org/10.1016/0264-2751(93)90045-K

Zhang, Y., \& Guan, X. (2018). Selecting project risk preventive and protective strategies based on bowtie analysis. Journal of Management in Engineering, 34(3), 04018009.

https://doi.org/10.1061/(ASCE)ME.1943-5479.0000603

Zhao, W., \& Schroeder, P. (2010). Sustainable consumption and production: Trends, challenges and options for the asia-pacific region. Natural Resources Forum, 34(1), 4-15. https://doi.org/10.1111/j.1477-8947.2010.01275.x

Zollo, M., Cennamo, C., \& Neumann, K. (2013). Beyond what and why: Understanding organizational evolution towards sustainable enterprise models. Organization \& Environment, 26(3), 241-259. https://doi.org/10.1177/1086026613496433 